\title{
Willingness to pay for Rainfall based Insurance by Smallholder Farmers in Central Rift Valley of Ethiopia: The Case of Dugda and Mieso Woredas
}

\author{
Hiwot Teshome Abebe ${ }^{1}$, Prof. Ayalneh Bogale ${ }^{2}$ \\ ${ }^{1}$ Department Agricultural Economics, Ethiopian Institutions of Agricultural Research, Ethiopia \\ ${ }^{2}$ Director \& Associate Professor, Africa Center for Food Security, University of KwaZulu-Natal, South Africa
}

\begin{abstract}
Current climate variability is already imposing significant challenge to Ethiopia. Therefore, farmers have faced income variability in almost every production season. Problems associated with dependence on rain fed agriculture are common in Ethiopia. Smallholder farmers' vulnerability from such income variability is also common. Over the years, a range of risk management strategies have been used to reduce, or to assist farmers to absorb, some of these risks. Since insurance is potentially an important instrument to transfer part of the risk, this study try to describe the nature of weather related risks faced by smallholder farmers, assess small holder farmers willingness to pay for the rainfall risk insurance and examine factors that affect the maximum farmers are willing to pay for the rainfall risk insurance. The data was collected from 161 sample households from the two woredas of the study area using closed ended value elicitation format followed by open ended follow up questions. The study uses Logit model to estimate the mean willingness to pay in the close ended format in addition with Tobit model to examine factors that affecting small holder farmer willingness to pay as well as intensity of payment. The mean willingness to pay values are found to be 129.98 and 183.41 birr per hectare for the open and close ended formats respectively. The total willingness to pay for the study area was found to be birr 5,740,244 per year. The tobit model shows six potential explanatory variables affect the willingness to pay value. Income of household and ownership of radio have positive and significant effect on the value of willingness to pay, whereas off-farm income, age of household head, number of livestock owning and availability of public and private gifts have negative and significant effect on willingness to pay value. If the rainfall risk insurance premium is affordable and households have enough information about the service they are willing to pay for the service. Eventually policy makers need to be aware that socio-economic and institutional characteristics of households influence the willingness to pay for rainfall risk insurance services.
\end{abstract}

Key words: Rainfall based insurance, Willingness to pay, Small heolder farmers, Tobit 


\section{INTRODUCTION}

\section{Background}

Agricultural producers around the world are exposed to a variety of income uncertainties, both market related, such as price variations, as well as non-market related, such as unstable weather patterns. It is well known that such uncertainties induce substantial income risks, and these can be particularly detrimental to small and/or poor producers in developing countries (Sarris, 2002).

A number of countries in Africa already face various challenges due to climate variability and recognize that adaptation is not an option but a necessity (Thornton et al., 2006). It is also well known that farmers have developed several ways for dealing with the various risks they face. Because climate change is expected to adversely affect agricultural production which remains to be the main source of income for most countries (Bryan et al., 2009).

A large array of adaptation practice is available to improve the resilience of smallholder agricultural system to uncertain future impact of climate change. Over the years, a range of risk management strategies have been used to reduce, or to assist farmers to absorb, some of these risks. These strategies include on-farm measures such as diversification or selecting less risky production methods, as well as strategies for sharing risk with others. Risk management strategies in which risks are shared with others include, among others, farm financing, share-cropping, price pooling arrangements, forward contracting of farm products, and hedging on future markets. Also insurance is potentially an important instrument to transfer part of the risks (Anderson, 2001).

Insurance markets are growing rapidly in the developing world, as part of this growth; innovative new products allow individual smallholder farmers to hedge against agricultural risks, such as drought, disease and commodity price fluctuations (World Bank, 2005). These financial innovations hold significant promise for rural households. Shocks to agricultural income, such as a drought-induced harvest failure, generate movements in consumption for households who are not perfectly insured, and at the extreme, may lead to famine or death.

Interest in developing catastrophic weather insurance products for rural dwellers in developing countries has grown radically in recent years. This interest has been fueled by the successful introduction of new products for the management of systematic risks to international financial markets in the recent years. Rainfall-based index insurance products for agriculture represent an attractive alternative for managing weather risk (Hellmuth et al., 2009). These products include catastrophic bonds and area yield crop insurance options, and their success suggests that it may be possible to package catastrophic weather and natural event risks facing developing countries and reallocate them to international markets in a cost efficient manner, bringing affordable risk management services to rural dwellers in agriculture dependent countries (Skees, 2001).

The demand for such insurance particularly in developing countries has been increasing over time, as a result of unpredictable weather conditions. In case of Ethiopia the impact that climate variability has on predominantly rain-fed agrarian economies is clearly demonstrated. Current climate variability is already imposing significant challenge to Ethiopia by affecting food security, water and energy supply, poverty reduction and sustainable development efforts, as well as by causing natural resource degradation and natural disasters. In response, the national adaptation program of action (NAPA) for Ethiopia has been prepared and the basic approach to NAPA preparation was along with the sustainable development goals and objective of the country where it has recognized 
necessity of addressing environmental issues and natural resource management with the participation of stakeholders (MoWR, 2007).

Agriculture, as in many other developing countries, is the mainstay of Ethiopian economy. Nearly $85 \%$ of the population earns its livelihoods and contributing over $43 \%$ of the GDP (Gross Domestic Product), about $90 \%$ of the foreign exchange earnings, a further $10 \%$ earn their living from livestock (CSA 2004) which is almost entirely small-scale and rain-fed. Both farmers and pastoralists are highly dependent on the climate for their livelihoods (World Bank, 2000). Ethiopia has recognized climate change as an important issue and attempts are being made to incorporate potential response measures for reducing impact of climate change in to over all development planning process. One important constraint that emerged as a result of stakeholder consultative meetings is the extreme need for agricultural rainfall risk insurance. It is believed that agricultural rainfall based insurance is seen as one of the strategies to minimize risk and capitalize on opportunities associated with the variable climatic conditions.

The high covariance of climatic risks, coupled with the lack of property to be attached as collateral, makes it difficult for cooperatives, microfinance organizations, or banks to provide financial services to smallholder farmers unless they have insurance/reinsurance against weather risk. These conditions in turn keep farming at a subsistence level. According to Stern (2007), adaptation to climate change and variability will be crucial in reducing vulnerability and is the only way to cope with the impacts that are inevitable over the next few decades. This research is therefore an attempt to look in to the possibility of rainfall based insurance existence in Ethiopia.

\section{Statement of the Problem}

The farming community on the globe in general and that of the least developed countries in particular is considered to have a risk aversion attitude (Anderson et al., 1977; Dillon and Hardaker, 1993). Hardaker et al., (1997) and Binswanger, (1980) have also argued that most smallholder farmers avers to risk-by and large, they are too poor to be otherwise.

Better decisions in risky world can always be made if information about more productive technology option, marketing opportunities and marketing trends are available. But almost all small scale farmers in the globe avers to risk because they are poor (Hardaker et al., 1997), which holds true for the farming community in Ethiopian central rift valley. This is because of the erratic rainfall in the area. Furthermore, weather related agricultural production shocks also conspire to keep smallholders within the poverty trap, preventing the country from reaching its productive potential in the agricultural field (Hess and Syroka, 2005). Agriculture is often carried out in open air, and always entails the management of inherently variable living plants and animals which are especially exposed to risk. Production risk comes from the unpredictable nature of the weather (Hardaker et al., 1997). And it is probably fair to claim that farmers in developing countries are exposed to most types of risk, and the low-income farmers, especially in semi-arid areas are the most exposed (Hazell 1992).

Ethiopia is among famine-prone countries in Africa and has a long history of famine and food shortage that can be traced back to 250 BC (Assefa and Ramakrishna, 2002). More than half of the food insecure African population lives in Ethiopia, Chad, Zaire, Uganda, Zambia and Somalia and the food insecure population in Ethiopia is estimated to be around 40-50 percent of the total population (Assefa and Ramakrishna, 2002). .

Therefore, farmers have faced income variability in almost every production season. Problems associated with dependence on rain fed agriculture are common in Ethiopia; 
repeated famine, crop failure, human and livestock loss are among the indicators (Assefa and Ramakrishna, 2002). Smallholder farmers' vulnerability from such income variability is also common in Ethiopian central rift valley and the two woredas of the study area, Dugda and Mieso. One major constraint to initialize the opportunity to operational riskcovering mechanisms like rainfall crop/input insurance in Ethiopia is absence of public and/or private institutions. In order to exploit the advantage associated with good rainfall seasons, risk financing institutions need to be encouraged to develop operational risk insurance schemes in the marginal rainfall areas.

This study tries to identify willingness to pay for rainfall based insurance by smallholder farmers in central rift valley of Ethiopia. The main issues and problems that need to be researched and analyzed in this study are: to investigate whether smallholder farmers are willing to pay for rainfall based insurance and identify factors that determine their maximum willingness to pay for the rainfall based insurance as well as explore the existing risk insuring mechanisms commonly used by small holder farmers. This study was, therefore, initiated to fill the current information gap and awareness on the subject.

\section{Objectives of the Study}

The objectives of the study are;

- To describe the nature of risks faced by small holder farmers in the study area;

- To assess the willingness to pay for rainfall based insurance by small holder farmers in the study area;

- To examine factors that affect the maximum farmers are willing to pay for rainfall based insurance in the study area.

\section{Significance of the Study}

The National development plan of the country is based on a strategy called Agricultural Development Led-Industrialization (ADLI), and aims at changing the country's subsistence or traditional agricultural to commercial or market oriented one, which in turn will increase the demand for goods and services and further lead to industrial development. The Government strategy is aimed at reducing country's dependency on food aid. To achieve the intended goals within a short period of time, understanding smallholder farmers' participation as well as their willingness to pay for rainfall based insurance will be vital. Reducing the vulnerability of rainfall dependent communities to climate change requires building of local institutions to support better adaptation practices where vulnerability is usually more clearly expressed.

This research looks also in to the willingness to pay for rainfall-index based insurance contracts that can promote more efficient program of actions in reducing problems of imperfect information in mitigating farmers' risks in Ethiopia. Therefore, identifying smallholder farmer's willingness to pay for rainfall based insurance is expected to be useful for policy makers in providing good information, for decision makers to make informed choices on where and how to intervene and funding agencies, involved in the development and promotion of weather based insurance. Even though the study was conducted in the Central rift valley of Ethiopia, the result can be applicable to other parts of the country which have almost similar climate condition. The outcome of this study is also expected to be useful for governmental and non governmental institutions who are involved in the weather based insurance service. 


\section{Scope and Limitation of the Study}

The scope of this study covers assessing willingness to pay for rainfall based insurance and examining socio-economic and institutional factors that significantly affect the amount of money farmers are willing to pay for rainfall based insurance. The proposed research is confined only to two woredas of the central rift valley, which can somehow represent other woredas of the Central rift valley of Ethiopia this is because of resource constraint to undertake the study at broader level. In addition, the data collected for 2010 are a onetime data this might not be enough to generate adequate information because there are many variables which could be potentially changed from one survey time to the other survey time. As the research uses contingent valuation method (CVM) the study is subject to all limitations associations with the method however, efforts have been made to minimize the limitations of the methodology.

\section{Organization of the Study}

The study is organized in five chapters. Chapter one deals with background, problem statement, objectives, scope and significance of the study. And the remaining chapter, two and three deal with review of theoretical and empirical literature related to weather related insurance (rainfall) and the research methodologies, respectively. Chapter four presents results and discussion of the study. Finally chapter five summarizes the finding of the study and gives policy implication and recommendation.

\section{REVIEW OF LITERATURE}

\section{Definitions and Concepts}

One common distinction between risk and uncertainty is to suggest that risk is imperfect knowledge where the probabilities of the possible outcomes are known, and uncertainty exists when these probabilities are not known but the distinction of what risk and uncertainty for the farmers is theoretically and practically not clearly defined (Hardaker et al., 1997). Risk is everywhere and is substantially unavoidable. It is often said that, in business, profit is the reward for the risk bearing, no risk, no gain

According to (Hazall et al., 2010), Risks can be characterized according to a number of elements, including: Covariance; the degree to which they are correlated across households within a community or region, ranging from independent (affecting one person) to highly covariate (affecting everyone at the same time); Frequency; How often they occur; Types and severity of losses incurred; Shortfalls in seasonal production and income, damage to assets and loss of life.

\section{Risks in Agriculture}

Agricultural production is a risky business. Farmers have faced a variety of price, yield and resource risks that make their incomes unstable and unpredictable from year to year. The friction due to risk may also contribute to a lag in agricultural incomes relative to those in other sectors of the economy. The people who need to concern themselves with risk in agriculture include farmers, farm advisors, and commercial firms selling to or buying from farmers, agricultural research workers, policy makers and planers. According to (Holden et al., 1991) the greatest risks to family welfare in agriculture are centered in rural areas, which specialize in annual food crops but which are marginal to the production of those commodities, it is poverty and even worse alternatives which bring about such production emphasis. Such strategies are doubly risky because they are often 
unsustainable environmentally. In such area, fluctuation in weather and production are around the critical margin of profitability which in the case of poor countries and people means at the margin of existence.

\section{Rainfall Based Insurance}

The concept of index-based insurance is not new. Proposals for this type of insurance were first articulated by Halcrow (1948) and Dandekar (1977). The Australian Government commissioned a feasibility study of rainfall insurance in the mid-1980s, but decided not to pursue it (IAC, 1986). Index-based insurance is a financial product linked to an index highly correlated to local yields. Contracts are written against specific perils or events (e.g. area yield loss, drought, hurricane, flood) that are defined and recorded at regional levels (e.g. at a local weather station). Indemnifications are triggered by pre-specified patterns of the index, as opposed to actual yields (Hazell et al., 2010).

Research carried out through the International Crops Research Institutes for the Semi-arid Tropics - Village Level Studies (ICRISAT VLS) suggested that rainfall lotteries are better than the crop insurance schemes to diminish rural household income variability in a costeffective manner in rain fed areas of India (Walker and Ryan, 1990). There would be a fair betting system and would be open to all households in the village. For instance, if landless labor households felt the demand for their labor was markedly reduced in low rainfall years, they could hedge their future labor income by purchasing tickets on the lowest or what they perceive to be the most adverse rainfall event.

Identifying weather risk for an agricultural producer involves defining the time period during which risk is prevalent, and identifying a measurable weather index that is strongly correlated to farmers losses on a particular crop. This is the most critical process in designing a weather risk management strategy. A weather index can be constructed using any combination of measurable weather variables, over any period of time and any number of weather stations (Walker and Ryan, 1990).

Problems with fixing insurance premium: three type of problems related to insurance premium are; adverse selection, covariate risk and moral hazard.

adverse selection: This occurs when potential borrowers or insures have hidden information about their risk exposure that is not available to the lender or insurer, which then becomes more likely to erroneously assess the risk of the borrower or insure.

Covariate risk: Risk that can affect large numbers of people at one time (e.g. widespread drought, flooding, earthquake).

Moral hazard: This occurs when individuals engage in hidden activities that increase their exposure to risk as a result of borrowing or purchasing insurance. These hidden activities can leave the lender or insurer exposed to higher levels of risk than had been anticipated when interest or premium rates were established.

\section{The Rural Poor and Risk Coping Strategies}

Siegel and Alwang (1999) developed taxonomy of risk-coping strategies for rural households facing risk. However, many strategies are unavailable or prove ineffective for the poor, especially when the risks are covariate. Households living on very low incomes and limited wealth become highly risk averse. Since even a small disruption in income flows can have devastating effects, such risk aversion retards the development process by limiting household incentives to adopt productivity-enhancing technologies and to specialize in activities where comparative advantages exist. Such risks also affect the credit-worthiness of rural households and constrain credit markets. Farmers, who are more risk averse with 
respect to losses, would be more likely to participate in crop and rainfall insurance programs and would be willing to pay higher premiums and individuals would include insurance in their risk management strategies if the insurance premium were less than the cost of other risk responses having the same effect (Patrick, 1988).

\section{Demand for Weather Based Insurance in Developing Countries}

Weather index-based insurance was being discussed in academic papers as an alternative solution for developing agricultural economies in developing countries. In 2002, donors began to finance the piloting of these ideas. In particular, the World Bank's Commodity Risk Management Group (CRMG) allocated trust funds from the Swiss and the Dutch governments to pilot weather insurance for farmers to complement its price risk management work in commodity markets.

Commodity Risk Management Group (CRMG) has been involved in many weather risk management technical assistance projects to commercial entities in the developing world. CRMG was involved in its first index-based weather risk management transaction in India in June 2003, the first-ever weather insurance project in the country. Since 2003 there have been several other pilots around the world, including completed pilots in Ukraine, Ethiopia, and Malawi, and upcoming pilots in Kenya, Tanzania, Thailand and Central America. Successes like the market growth in India have had significant demonstration effects and have proven that weather risk management for farmers in the developing world is possible through insurance -type instruments (World Bank, 2007).

\section{Traditional Crop Insurance versus Weather Index Insurance}

Traditional multiple-peril crop insurance that indemnifies losses on individual farm basis is subject to high administrative costs in order to overcome the problems of adverse selection and moral hazard. It also requires significant investment in monitoring farm yields to prevent both higher losses than the initial rating and serious actuarial problems. Furthermore, multiple-peril crop insurance has large correlated risks, so it requires the extra cost of providing reinsurance. These extra costs can be quite high in an emerging economy with little or no experience in providing insurance of this type. These conditions mean that traditional multiple-peril crop insurance is not a workable solution for most of agriculture in developing countries (Hess and Syroka, 2005). One form of agricultural insurance that mitigates these added costs is weather insurance. Payout is determined by an objective parameter such as millimeters of rain, soil moisture, etc. Weather index insurance was found to be well suited to the agricultural production in regions in Ukraine where there are wide spread crop losses due to drought and frost (Hess and Syroka, 2005). The monitoring costs of weather insurance are less as there is no need to perform farmlevel loss adjustments and the balance of information about the weather is equally shared by the insured and the insurer (unlike with traditional farm-level insurance where the farmer will always know more about the yield than the insurer). Thus, weather insurance could be a preferred alternative to crop insurance, as it avoids moral hazard problems and high administrative costs. Furthermore, the reinsurer is more likely to provide better terms when the insurance is based upon weather events and not farm-level losses.

\section{Standard Approach to Develop a Weather Insurance Pilot}

The World Bank (2007) has drawn some lessons from its work and begun to develop a standardized approach to pilot implementation as well as contract design. While this approach is still evolving, there are seven basic components of pilot program implemen- 
tation that need to be undertaken in order to develop a product that is not only technically sound but is demanded and can be afforded by clients:

- Identify potential pilot areas and carry out a basic risk assessment,

- Identify delivery channels for reaching the end users,

- Design contracts,

- Determine the marketability of the products,

- Finalize contracts and insurance,

- Market the product, and

- Monitoring the pilot.

\section{Methods of Valuation}

The farmer's decision to purchase rainfall insurance and the maximum premium he/she is willing to pay can be considered in the framework of maximizing net benefits from nonmarket goods and services. The principles that non-market goods and services are not efficiently allocated by the market suggests the possibility of improvement in measurements of benefit and costs.

According to Freeman (2003), the widely used methods of valuation of some non-market goods and services are revealed and stated preference methods. Revealed preference methods are based on the actual behavior reflecting utility maximization subject to constraint.

\section{Revealed preference method}

Revealed preference methods are based on the actual behavior reflecting utility maximization subject to constraint. One type of the revealed preference method is based on the observed choices in a referendum way. If an individual is offering a fixed quantity of a good price on a take it or leave it or yes or no basis, observation of the choice reveals only whether the value of the offered to the individual was greater than or less than the offered price. The other methods for valuation of non-market goods under revealed preference techniques are the Hedonic Price Method (HPM) or Property Value Method, where the change in the environmental amenity is reflected in the value attached to the amenity and Travel Cost Approach (TCA) where it mostly used to capture the recreation value of sites, such as national parks and sanctuaries. The travel cost approach is applied to determine the influence of various socioeconomic characteristics and the nature of demand for recreation site (Marothia, 2001). However, revealed preference models can not measure existence value or option value. So, firstly they cannot measure total economic value (TEV) and secondly while RP models measure the household's WTP, one cannot be sure that the price captures all the effects.

\section{Stated preference method}

Stated Preference Method uses a direct approach to elicit willingness to pay, this method involved asking people directly about the values they place on non-market services by creating in effect, a hypothetical market (Freeman, 2003). Among the frequently used methods of stated preference, the Choice Modeling and Contingent Valuation Method (CVM) are the commonly used ones Choice Modeling do not ask questions directly; instead they ask people to rank alternatives, whereas, CVM is used when market do not exist for environmental resources by asking questions directly (Mitchle and Carson, 1989; Hausman, 1993). 
The valuation is done based on hypothetical or non-existing market. The valuation task is therefore, to determine how much better or worse off individuals will be as a result of change in non-market goods. Among the commonly used methods of the stated preference contingent valuation method is widely used.

\section{Contingent valuation method}

Contingent valuation method as one of the stated preference methods, is basically uses a survey based approach. The decision to use willingness to pay (WTP) or willingness to accept (WTA) depends on, among other things, individuals' perception as to who has the property right over their source in question (Carson et al., 2001). This is computed by asking how much people are willing to pay for a non-market goods (WTP) or how much they are willing to give up having a specified non-market goods quality improvement happen (Freeman, 2003). When market data are unavailable or unreliable, economists can use alternative estimation methods that rely on hypothetical market conditions. Such methods typically use surveys to inquire about individuals' willingness to pay (WTP) for some environmental policy initiative. This survey approach to benefit estimation is known as the contingent valuation method (CVM) because the results are dependent up on the hypothetical market devised. In general, CVM helps researchers to capture the total value of the good both use and non-use values and its flexibility facilitate valuation of a wide range of non-marketed goods. As a result, this method is becoming the most preferred valuation method at present. The major problems with this approach have largely to do with the specification of the "scenario" or the "benchmark" against which the agent is supposed to compare the current situation, and express a monetary value for what it is worth to him/ her to move to the new situation, or avoid a bad one

There are number of different elicitation methods used in CVM. Dichotomous and open ended are among the methods used for obtaining the WTP. The open ended question asks the respondent how much he or she is willing to pay for given change in the status quo. This means individuals are asked for their maximum willingness to pay with no value being suggested to them. The other method is dichotomous choice question whereby a respondent is asked if he or she is willing to pay a specific amount of money for a pre specified change (Bateman et al., 2000)

The use of specified format has got the advantage over the open-ended format question in eliciting WTP because of the simplicity for respondents and reduced incentives for strategic responses (Bateman et al., 2000). In the dichotomous method, if the first bid given to the respondent is accepted, a second somewhat higher offer price is made. If the first bid is refused, the second bid price offers is somewhat lower, the bid levels offered in the follow up question will be greater than that offered in the initial payment if the answer to the initial payment question is "yes" and vice v ersa. Finally the dichotomous choice question is followed by an open-ended follow up question (Alberini and Cooper, 2000).

Biases in CVM: criticism on CVM is, since individuals are being given a hypothetical market their responses could be far from reality. Thus there will be biases, which can systematically understate or overstate true values. There are a number of types of biases indicated, some of them are:

Strategic Bias: This occurs when the respondent tries to understate or overstate the bid value so as to influence the outcome. For instance, if the CVM requires payment of a tax the respondent may strategically understate the bid value to influence the outcome. Using the take-it-or-leave it method, Mitchell and Carson (1989) suggests that, deleting protest bids and remove all outliers are the ways to tackle this bias. 
Hypothetical Bias: This arises due to the hypothetical nature of the market in CVM surveys which can render respondents' answers meaningless if their declared intentions cannot be taken as accurate guides of their actual behavior. Experimental trials suggest that this problem is less when one uses WTP format instead of WTA format.

Information Bias: The quality of information given in a hypothetical market scenario almost certainly affects the responses in a CVM Survey. Inadequate or improper presentation of information on the good or service to be valued can bias the quality of the CVM study. Besides by making respondents feel that the hypothetical market is realistic, and avoiding WTA format can remove information bias.

Starting Point Bias: The suggestion of an initial starting point in a bidding game can significantly influence the final bid. For example choosing a low (high) starting point leads to a low (high) mean WTP.

Interviewer and Respondent Bias: The interviewer's conduct and interviews can influence responses. Though this kind of bias can be minimized by using mail or telephone surveys, this will result in less information forthcoming and also give rise to hypothetical bias. Respondents may not give correct answers or give the questions proper consideration. Therefore, to minimize this problem, professional interviewers should be used or well trained interviewers to reduce this type of bias.

\section{Willingness to pay (WTP) and willingness to accept (WTA)}

Willingness to pay and willingness to accept are two methods for elicitation of values. WTP is the amount that must be taken away from the person's income while keeping his utility constant in the same manner, WTA for a good is defined as the amount of money that must be given to an individual experiencing deterioration in environmental quality to keep his utility constant. The decision to use willingness to pay (WTP) or willingness to accept (WTA) depends on, among other things, individuals' perception as to who has the property right over their source in question (Carson et al., 2001). This is computed by asking how much people are willing to pay for a non-market goods (WTP) or how much they are willing to give up having a specified non-market goods quality improvement happen (Freeman, 2003).

In theory, when WTP is a small fraction of income, WTP and WTA for a given commodity should be approximately equal. However, a number of CV studies have found that WTA is often much larger than WTP for the same commodity. One explanation is that the difference between WTP and WTA depends on the elasticity of substitution between the commodity to be valued (a public good) and private substitutes. The lower the elasticity, the fewer will be the available substitutes and the greater the difference between WTP and WTA (Hanemann, 1991).

Another explanation - the theory of prospects - is that individuals value losses more heavily than gains. It is also possible that individuals react to their perception of who has the property rights over the commodity in question. If the proposed policy contradicts their perception of the existing property rights, individuals might express their rejection of the scenario through high WTA values. Carson (1991), suggests that WTP should be used whenever the individual might incur benefits from the proposed policy, and Mitchell and Carson (1989), offer ways to frame the payment question to elicit WTP.

However, even when the individual might incur benefits from the proposed policy, there are some scenarios under which the respondent may not overstate WTA values (Cooper and Osborn, 1998). Moreover problem with direct WTP studies involves the fact that reported values are likely to be influenced by recent experiences. For instance, farmers are 
more likely to express high demand for drought insurance if weather in recent periods has been adverse. There are also several technical issues concerning the method of deriving the WTP from either direct expression of values, or contingent rankings of alternative choices, but these seem to have been largely resolved (Hanemann and Kanninen, 1998).

\section{Empirical Studies on Demand for Agricultural Insurance}

The review presented in this section shows the logical reasons forwarded by different researchers about the demand for agricultural insurance by farm households, factors including socio-cultural, economical and institutional. There are very few studies relevant to agricultural insurance that use the CV approach. Patrick (1988), analyzed producers' demand for a multiple peril crop insurance (MPCI) program with indemnities based on actual yields, and a rainfall insurance program with indemnities based on area rainfall. Tobit regression analysis was used to estimate responses utilizing information from the participants and non-participants in the hypothetical programs. He found that expected wheat yield had a negative effect on the premium, and suggesting that an area crop insurance program might encounter difficulties of adverse selection. Area in wheat had positive relation to premium paid for crop insurance whereas age has negative relation to premium paid for crop insurance. Farmers who are legume producers and those who are averse to risk would be willing to pay higher crop insurance premium.

The finding of this study is showed that the participation in the crop and area rainfall insurance programs would be limited. One quarter of the producers would participate in the crop insurance program and over one half would not participate in the rainfall insurance program. Twenty percent or less of the producers would be willing to pay the estimated full costs of the insurance programs and the author suggests very limited potential for commercial establishment for programs under current circumstances of drought assistance. In developing country context, the study by McCarthy (2003) found considerable demand for weather-based wheat insurance in Morocco farmers. The indirect methods of estimating WTP involve first the specification of a model of the random income or other variable of direct relevance to the farmer's welfare (e.g. consumption), the information from formal sources e.g. radio, television in fact has a negative impact on demand, indicating that those who keep better informed of rainfall at the station are less likely to prefer any insurance counteract. The result showed that explanatory variables had ambiguous impacts differed both quantitative and qualitative across and within the region. The author concluded that demand for insurance, however, appears to be quite distinct across the different areas, which indicates the need for larger data sets to satisfactorily estimate the determinants of the willingness to pay. The author also expresses the WTP as the amount of money that would equate the expected utilities of the relevant variable with and without the insurance. This amount of money (the premium) is then estimated for objectively estimated values of the risks with and without the insurance, and for a range of relevant utilities, or relevant parameters (such as degrees of risk aversion) from a given class of utilities.

The study by Gautam et al. (1994), where the farm household's behavior is assumed to be described by the maximization of the expected value of inter temporal utility function. The production, saving, labor allocation, diversification, borrowing, and insurance decisions are assumed to be endogenous. The equilibrium conditions of the optimization problem are manipulated to infer the production and diversification decisions of the household as functions of both standard variables as well as a variable that measures the relative preference of the household for risky versus non-risky income.

The same approach is essentially followed by Sakurai and Reardon (1997), who utilized 
panel data for Burkina Faso. The additional feature of this study is that the researchers regress their estimates of farm level demands for drought insurance on a set of variables, so as to identify variables that increase or decrease such demand. They found as expected, that the demand for drought insurance depends on the perceived probabilities of droughts, and is higher for regions with higher such probabilities. They also found that variables such as the size of cultivated area, and the age of household head significantly affect positively the demand for insurance, while the amount of off-farm income, the availability of public aid and private gifts, and the size of household significantly affect negatively the demand for insurance.

\section{Experience of Ethiopia}

In recent years Nyala insurance has provided two types of crop insurance: multiple-peril crop insurance (MPCI) and index-based weather insurance, each designed to meet the needs of different farmers. Nyala's MPCI is a double-trigger scheme that insures farmers against a number of different shocks both natural and human caused that affect crop yields, including shortages of rainfall, excess rainfall, fire, and transit risks. Because MPCI insures against a number of perils, it is better suited to farmers who face a number of sources of risk to crop yields than it is to farmers whose predominant source of risk is rainfall variability. Since 2009, Nyala Insurance Corporation introduces and sells weather index insurance through farmer cooperatives, taking advantage of low-cost automatic weather stations owned by the National Meteorological Agency (Hazell 2010) this is specifically to protect smallholder farmers against weather risk. This product was provided in cooperation with Oxfam-America, mainly using satellite data and a weather index product was designed in collaboration with the World Food Program around the rainfall requirements of different crops. Currently, Nyala insurance has found that farmers' unions serve as effective delivery channels for the weather insurance products.

\section{Research Methodology}

\section{Description of the Study Area}

This study is under taken Dugda and Mieso woredas. These woredas are among the central rift valley woredas of Ethiopia. Dugda woreda is located in eastern Shoa zone of Oromia region. Dugda woreda, the capital is Meki, is located about $175 \mathrm{~km}$ south of Addis Ababa. It has a total population of 144,849 (CSA, 2008). The altitude ranges from 1610-2020 m. a. s .1. Because of its location in semi-arid type of ago-ecology, the woreda has a bimodal and erratic type of rainfall with high variation between and within years. The woreda has a total of 36 Peasant Associations (PAs).

Crop-livestock mixed farming system characterizes agriculture in the woreda. Cattle, goats, sheep and chickens are important livestock species reared by farmers. Maize, teff, wheat and haricot bean are major crops grown by farmers. Besides cereals and pulses farmers in the woreda produce significant amount of horticultural crops particularly vegetables. Onion, tomato, pepper and cabbage are the most widely grown vegetable crops

Meiso Woreda is located $300 \mathrm{~km}$ east of Addis Ababa, and at about $200 \mathrm{~km}$ east of Adama town. It is located west and is one of Somalia region woredas in Oromia where agro pastoral farming system is practiced. The woreda has a total number of 37 rural kebeles and four town dwellers' associations. The total human population of the woreda is estimated at 145,775 , and is composed of 22,012 agricultural rural households and 6785 urban households. The total rural population is 115,568 , out of which $58,612(51 \%)$ are males. Of 
the total rural households, 17,495 (80\%) are male-headed households.

The woreda has a total area of $2573.44 \mathrm{~km}^{2}$ (about 257,344 ha) and is situated between

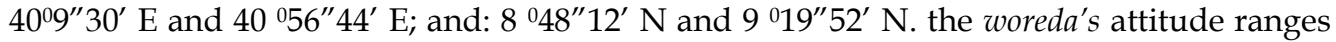
between 900-1600 masl. The mean annual temperature varies between $24^{\circ} \mathrm{C}-28^{\circ} \mathrm{C}$. The mean annual rainfall ranges from 400 to $900 \mathrm{~mm}$, with an average of about $790 \mathrm{~mm}$ (IPMS 2006). Agro-ecologically, the woreda is classified as lowland (Kolla). The area receives a bimodal rainfall where the small rains are between March and April while the main rains are between July and September. During the small rains, are unpredictable and erratic, and as a result, crops fail in most years due to lack of even distribution of rainfall.

Recurrent drought is a major problem, and is making relief aid a regular source of livelihood for many rural families. A total land area of 22,487 ha (about $12 \%$ of the woreda) is considered suitable for crop production.

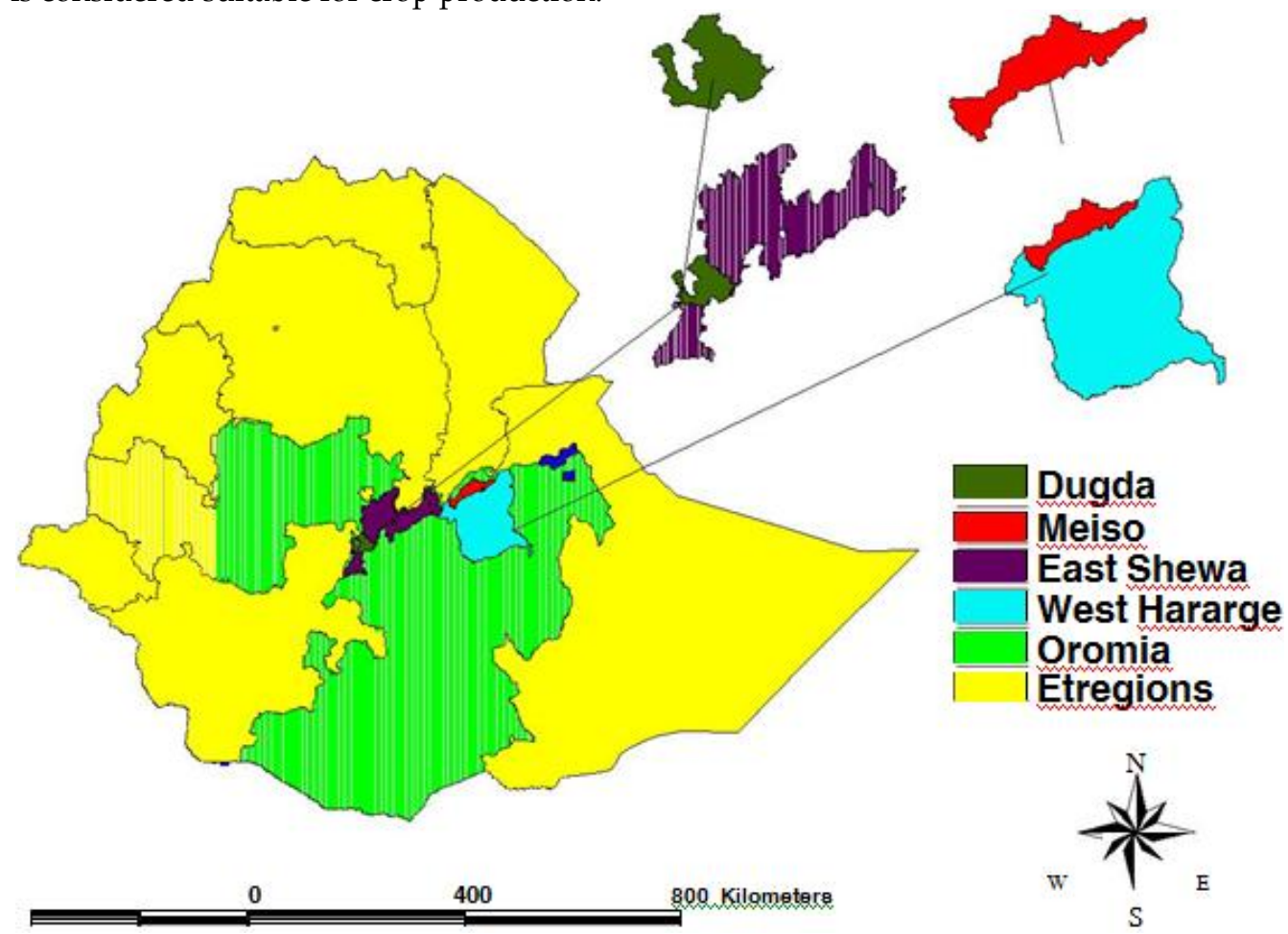

Figure 1. Location of the study area

\section{Sampling Techniques and Method of data Collection \\ Sampling techniques}

A multi stage sampling technique was used to select 161 sample households. In the first step of the sampling, out of the woredas in the central rift valley that have almost similar climate condition, Mieso and Dugda woredas were purposively selected because these areas are most drought prone areas. In the second stage, out of the 36 PAs in Dugda woreda 4 PAs were selected randomly and of 36 PAs in Mieso woreda 3 PAs were selected. In the third stage the total numbers of households in each PAs were listed and finally a total numbers of 161 sample households were selected and interviewed based on the proportional to sample households.

Table 1. Number of household and sample sizes 


\begin{tabular}{|c|c|c|c|c|c|}
\hline Woreda & No of PAs & $\begin{array}{l}\text { Farming } \\
\text { system }\end{array}$ & Name of PAs & $\begin{array}{c}\text { No of HH in } \\
\text { PAs }\end{array}$ & Sample HH \\
\hline \multirow[t]{4}{*}{ Dugda } & 4 & Mixed & B/Gusaa & 344 & 18 \\
\hline & & Mixed & Jawe Bofo & 332 & 16 \\
\hline & & Mixed & Odd Bokota & 496 & 24 \\
\hline & & Mixed & S/Wakalee & 474 & 23 \\
\hline \multirow[t]{3}{*}{ Mieso } & 3 & Agropastoral & Buri Mulu & 584 & 29 \\
\hline & & Agropastoral & Chobi & 500 & 24 \\
\hline & & Crop-livestock & Husemandhera & 551 & 27 \\
\hline Total & 7 & & & 3281 & 161 \\
\hline
\end{tabular}

\section{Method of data collection}

Data were gathered from primary and secondary sources. The primary data were collected from sample households through a structured questionnaire using face to face interview as well as CVM was employed to collect willingness to pay data. The secondary data were collected from the existing government line departments and offices, records of non-governmental organizations. In addition a structured questionnaire focus group desiccation was done with a group of farmers in each woredas PAs to know major sources of risk and management strategies practiced. Six enumerators who speak the local language were recruited from the study area and trained on interviewing techniques and how to manage $\mathrm{CV}$ questions.

\section{Method of WTP data collection}

Willingness to pay is defined as the amount that must be taken away from household's income. The willingness data is collected through CV method, this method is also suited to solicit consumers' willingness to pay for a product that is not yet on the market. CVM is now increasingly used in developing countries (Alberini and Cooper, 2000). In this method, the researcher creates a hypothetical market in a non-market or new good. The values which are generated through this hypothetical market are treated as estimates of the value of new good. After designing the draft questionnaire pre test was conducted with 26 randomly selected sample households. An open ended question was used for the elicitation of the respondents' maximum amount they are willing to pay for the insurance service per hectare. This is due to make some modifications in the designed questionnaire of the survey and to obtain starting bid values. Based on this elicitation some values were selected as the starting bid values for the survey questionnaire. The bid values were distributed randomly through 161 sample households and the respondents were asked are you willing to pay this amount if the respondent says yes or no, finally the single bounded dichotomous choice question is followed up by an open-ended follow up question.

\section{Method of Data Analysis}

The data that had been collected through contingent valuation method has been analyzed using both descriptive statistics and econometric model. Descriptive statistics such as mean, percentage, standard deviation and frequency of appearance was used, whereas on the econometric approach adopted the Tobit model.

\section{The Tobit model}

A very common problem in microeconomic data may stem from conditions in which the researcher had information only on the regressors but not on the regress and (amount of the respondent is willing to pay for rainfall insurance) for some observations. A sample in which information on the regress and is available only for some observations is known as a censored sample. When data are censored, the distribution that applies to the sample 
data is a mixture of discrete and conditional distribution and the most appropriate model to analyze such distribution is the Tobit model.

This model is also commonly known as censored normal regression model (Greene, 2003). It assumes that many variables have a lower or upper limit that is known as threshold value and take on this limiting value for a substantial number of respondents. For the remaining sample respondents the variable takes on a wide range of values above the limit. The explanatory variables in the model may influence both the probability of limit responses and the size of non-limit. The two parts correspond to the classical regression for the non limit (continuous) observations and the relevant probabilities for the limit (zero) observations, respectively. Based on the above behavior of the model, Tobit analysis is appropriate for this study and the formula for the Tobit model is given as follows:

Following Long (1997), the structural equation of tobit model censored from below can be expressed as:

$$
\begin{aligned}
Y_{l}^{*} & -\mathrm{x}_{l} \beta_{t}+\varepsilon_{l} \ldots \ldots \\
Y_{l} & =Y_{t}^{*} \text { if } Y_{l}^{*}>0 \\
& =0 \text { if } Y_{t}^{*} \leq 0
\end{aligned}
$$

Where,

$Y_{i}=$ the observed dependent variable, in this case the maximum willingness to pay the respondent is willing to pay in Birr.

$Y_{i}^{*}=$ the latent variable which is not observable.

$X_{i}=$ vector of factor affecting willingness to pay.

$\beta_{i}=$ vector of unknown parameters to be estimated .

$\varepsilon:=$ residuals that are independently and normally distributed with mean zero and constant variance $\delta^{2}$.

The model parameters can be estimated by maximizing the tobit likelihood function of the following form (Maddala, 1997);

$$
L=\prod_{r_{i}>0} \frac{1}{\sigma} f\left(\frac{Y_{i}-\beta_{i} X_{i}}{\sigma}\right) \prod_{Y_{i} \leq 0} F\left(\frac{-\beta_{i} X_{i}}{\sigma}\right)
$$

Where $\mathrm{f}$ and $\mathrm{F}$ are respectively, the density functions and cumulative distribution function of $y_{i}^{*} \Pi y_{t}^{*}>0$ means the product over those $i$ for which $y_{i}^{*}>0$, and $\Pi y_{i}^{n}<0$ means the product over those $i$ for which $y_{i}^{*}<0$.

Maddala (1997) proposed the following techniques to decompose the effects of explanatory variables into the decision to pay and intensity effects. Thus, a change in $X$ (explanatory variables) has two effects. It affects the conditional mean of $Y_{i}^{*}$ in the positive part of the distribution, and it affects the probability that the observation will fall in that part of the distribution. Similar approach will be used in this study.

- The marginal effect of an explanatory variable on the expected value of the dependent variable is:

$$
\partial E\left(Y_{l}\right) / \partial X_{i}=F_{(z)} \beta_{l}
$$

Where, $\beta_{1} X_{1} / \boldsymbol{\delta}$ is denoted by $z$, and $F$ is cumulative distribution.

- The change in the probability of willingness to pay as independent variable $X_{i}$ changes is:

$$
\partial F(Z) / \partial X_{t}=f(z) \beta^{\prime} / \delta \text {. . }
$$


- The changes in the amount of money respondent are WTP with respect to a unit change in an explanatory variable among those who are willingness to pay are:

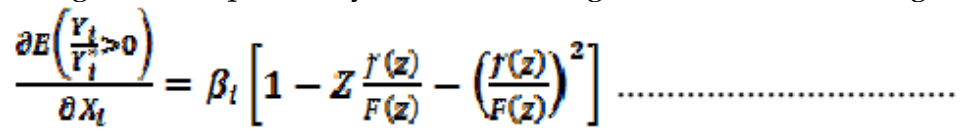

Where;

$\mathrm{F}(\mathrm{z})=$ is the cumulative normal distribution of $\mathrm{z}$,

$\mathrm{f}(\mathrm{z})=$ is the value of the derivative of the normal curve at a given point (unit normal density),

$\mathrm{z}=$ is the $\mathrm{z}$ score for the area under normal curve,

$\square=$ is a vector of Tobit Maximum Likelihood estimates and

$\sigma=$ is the standard error of the error term.

\section{The logit model}

In the logit model of single bounded dichotomous format, households are given initial bid value in which they may accept or reject. In the logit model the dependent variable is dummy variable yes/no. The purpose of the Logit model is to estimate the mean WTP. Following Gujarati, (1999) the Logit model is expressed as follows:

$$
\text { Logit }(P(x))=\beta_{o}+\beta x_{l}+s_{\imath}
$$

Where:

$$
\begin{aligned}
& p(x)=\text { probability that a given household is willingness to pay } \\
& \beta_{0}=\text { Constant term } \\
& \beta_{t}=\text { regression coefficient to be estimated or Logit parameter } \\
& x_{t}=\text { initial bid value } \\
& a_{t}=\text { error term of the Logit regression }
\end{aligned}
$$

One of the main objectives of estimating an empirical WTP model based on the CV survey responses is to drive a central value or mean of the WTP distribution Hanemann et al (1991). According to Gujrati (1999) both probit and logit models provide similar results thus, for comparative computational simplicity logit model was used for the estimation. And the mean willingness is formulated as:

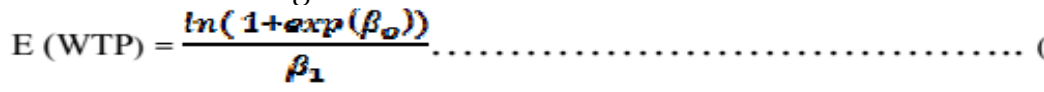

Where:

$$
\begin{aligned}
& \beta_{1}=\text { bid coefficient } \\
& \beta_{0}=\text { constant term }
\end{aligned}
$$

\section{Variable Definitions and Hypothesis \\ Dependent variable}

The amount of money the respondent is willing to pay for rainfall based insurance service per hectare was taken as the dependent variable.

\section{The independent variables}

It is very important to identify the potential explanatory variables and describe their measurements in a model. Therefore, based on review of theoretical and empirical works, Socio-economic characteristics of the households and institutional factors were considered 
as in the model.

Age of household (AGE): Age is continuous variable defined as the age of the head of farm household at the time of interview measured in years. According to the study by Patrick (1988) the age of the household has negative effect on the demand for insurance. The other study which has almost similar result with Patrick is Gine et al. (2007), who found that young farmers are more likely to purchase insurance than elders. Therefore, in this study it is hypothesized that young farmers are more likely to purchase insurance than elders.

Sex of household (SEHH): This is measured as a dummy variable taking the value of 1 for male headed household and 0 otherwise. The sex of the household head was included to differentiate between male and female household heads in their participation of making a decision on income distribution. In this study it is hypothesized that male head households are likely to purchase the insurance service than female head households. Therefore, it is expected to affect willingness to pay for rainfall based insurance positively.

Marital status of household (MRST): Marriage is social engagement to support each other both socially and economically. Married households put aside some of resources for unforeseen circumstances to smoothen their life, pool their resources and reduce cost that would have been spent separately. In this study marriage and willingness to pay for rainfall based insurance premium are hypothesized to be related positively.

Location of the study area (NAWO): This is dummy variable taking 1 , if the study area is located in Dugda and take 0, if the area is located in Mieso woreda.

Income from crop (FINC): It is a continuous variable expressed in Birr and shows the amount of income that the household head earned from crop production activities. The increase in demand for insurance associated with income and it appears that an increase in an income may create pressure on the household to purchase additional insurance. This is based on economic theory, which states that individual's demand for most commodities or services depend on income (Mbata, 2006). Vince and Joyce (1994) have found that income of the household has positive impact on the demand for rainfall based insurance. That is financial security for households with greater income may warrant additional protection. In this study income from crop is expected to have positive influence on farmers' willingness to pay for rainfall based insurance.

Off-farm income (OFINC): It is income from other non farming activities like basketry, roping etc. It is a continuous variable measured in Birr. A study conducted by Sukurai and Readon (1997) showed that respondents who received high amount of income from other non-farm activities are not interested in participating in drought insurance. Therefore households who have less amount of off-farm income are expected to be more willing to pay for rainfall based insurance.

Family Size (FSIZE): It is a continuous variable measured in number of people living under one roof. Higher family size is accompanied with larger household expenditure, which consequently depletes household cash resources. Sukurai and Readon (1997) have shown that as size of household increase, demand for insurance decrease. In this study size of household is expected to have negative effect on the willingness to pay for the rainfall risk insurance.

Dependency ratio (DEPR): This is a continuous variable measured in ratio. It refers to an increase in working-ratio that reduces the ability to meet subsistence need and also 
increase the personal rate of time preference. It also tells us the proportion of household members who are dependent on the economically active members of the family. The more dependency ratio in the household, the less active labor force the family would have. Paulos (2002), has found that it is negatively related to willingness on decision of the farmers to participate in soil and conservation practices. Therefore in this study it is expected to affect the expected willingness to pay for rainfall based insurance service negatively.

Education of household head (EDUC): It is dummy variable taking 1 if the respondent is literate and 0 if the respondent is illiterate. Education may increase farmers' ability to use information as well as practice. Education has been shown to be positively related to farmers' willingness to pay for willingness decision of the farmers to participate in soil and conservation practices (paulos 2002). Therefore, it is hypothesized to have a positive influence on farmers' willingness to pay for rainfall based insurance.

Availability of public and private aid (PAPA): Gifts may be in kind or in cash from governmental and other nongovernmental organizations. This is a dummy variable takes the value 1, if households have gift from different sources 0 , otherwise. The result from the study by Sukurai and Readon (1997) showed that as the availability of public and private aid is high, participation and willingness to pay for insurance is low. Therefore in this study availability of such aid expected to have a negative influence on the willingness to pay for rainfall based insurance.

Credit constraint (CREDIT): It is dummy variable which takes the value 1 , if the household has high credit constrained and 0, if less constrained. A study conducted by Gine et al. (2007) indicates that insurance participation is higher when households are less credit constrained. In this study credit constraint is expected to have a negative effect on the demand for insurance and willingness to pay for it.

Extension service access (EXTENTION): It is a dummy variable which takes a value of 1, if the farmer has access to extension service and 0 otherwise. Access to extension service indicates to the availability and existence of technical advices to stallholder farmers in the study area. Extension service widens the farmer knowledge with regard to use of improved seed and agricultural technologies. And has positive impact on household farm and decision for willingness to pay for rainfall based insurance. (Paulos, 2002) have found Extension access to farmers influenced the application of soil conservation technologies positively. In this study it is hypothesized that expected to affect willingness to pay positively.

Initial bid value (BID): This is continuous variable measured in Birr and included in the regression analysis to check weather starting bid bias exist or not. If this variable is significant and positive there is a bias on the starting bid value otherwise not.

Livestock holding (TLU): It is a continuous variable which represent livestock holding of the respondent in tropical livestock unit. It is expected to influence the willingness to pay of the household head either positively or negatively. This is because of the fact that the income from sale of livestock as well as production of livestock have positive influence on income and in turn income has positive influence for willingness to pay. Therefore, On the other hand, it may have negative impact on willingness to pay if the farmers believe that, as the willing to pay amount increases they might have to shift their attention from crop production to livestock production activity. In this study, it is expected to have negative 
influence on the willingness to pay for rainfall based insurance.

Ownership of radio of the household (RADIO): This variable is a dummy variable, which takes the value of 1 if household has radio and 0 otherwise. Radio is a source of information and can enhance the ability of farmers' access to different sources of information such as extension service, credit service, use of new technologies, improved seed varieties, input price, output price, crop protection, post harvest handling techniques than those farmers don't possess radio. Thus, farmers who have radio might be able to understand those information's earlier than those who do not have. Therefore, in this study it is hypothesized that owner of radio will be positively related to willingness to pay for rainfall based insurance service.

House type of the households (HOUSE): It is a dummy variable that takes the value 1 if the household has iron roofed house and takes the value 0 , if they have grass roofed house. Since type of house is a proxy for wealth status it may have positive influence on the farmers' willingness to pay for rainfall based insurance. In this study, it is expected to have positive influence on the WTP.

Table 2.Variables and their measurement included in the mode

\begin{tabular}{llll}
\hline Variable & Code & Type of variable & Definition and Measurement \\
\hline Age of the household & AGE & Continuous & Age of household head in years \\
Sex of the household & SEHH & Dummy & Sex of household head 1, if male 0, otherwise \\
Marital status & MRST & Discrete & Marital status 1, married 2, single 3, divorced \\
Location of the study area & NAWO & Dummy & Location of the study area 1, if in Dugda 0, in mieso \\
Family size & FSIZE & Continuous & Number of family members \\
Income from crop & FINC & Continuous & Total annual income of the households from crops in Birr \\
Education of the household & EDUC & Dummy & Education status of HHH, 1 if literate 0, otherwise \\
Off-farm income & OFINC & Continuous & Total off-farm income measured in Birr \\
Initial Bid value & BID & Discrete & Initial bid value offered in Birr per hectare \\
Maximum willingness to pay & MWTP & Continuous & Maximum WTP in Birr per hectare \\
Credit constraint & CREDIT & Dummy & 1 if the household is highly credit constrained 0, otherwise \\
Extension service & EXTENTION & Dummy & 1 service user 0, otherwise \\
Livestock holding & TLU & Continuous & measured in tropical unit \\
Dependency ratio & DEPR & Continuous & measured in Birr \\
House type & HOUSE & Dummy & 1 if iron roofed 0, otherwise \\
Owning radio & RADIO & Dummy & 1 if owning radio 0, otherwise \\
Availability of public and private aids & PAPA & Dummy & 1 if household head has aid 0, otherwise \\
\hline
\end{tabular}

\section{RESULTS AND Discussion}

The number of sample households included in this study was 161 . Both descriptive and econometric analyses were used in analyzing the data obtained from the survey.

\section{Descriptive Statistics Results}

Descriptive statistics such as mean, minimum and maximum values, range and standard deviations were used to describe the major factors explaining farmers' willingness to pay for rainfall risk insurance. In addition, mean difference for continuous variables and frequency of discrete variables were tested using t-test and chi-square test respectively.

\section{Household characteristics}

From the total surveyed respondents $144(89.4 \%)$ were willing to pay for rain fall based 
insurance where as the rest $17(10.6 \%)$ were not-willing to pay for the service. Based on the survey result, of the interviewed households 155 (96.3\%) were male respondents while the remaining $6(3.7 \%)$ were female respondents. Out of willing respondents, $141(97.9 \%)$ were male respondents and $3(2.1 \%)$ were female respondents, while out of non-willing respondents $14(82.4 \%)$ were males and $3(17.6 \%)$ were female respondents. The result of chi-square test shows that there is statistically significant difference in sex of household heads between willing and non-willing groups $(\mathrm{p}<0.01)$.

Of the total respondents, $147(91.3 \%)$ were married, $7(4.3 \%)$ were single, $5(3.1 \%)$ were divorced and $2(1.2 \%)$ were widowed. Out of the willing respondents, $133(92.4 \%), 7$ $(4.9 \%), 3(2.1 \%)$, and $1(0.7 \%)$ were married, single, divorced and widowed, respectively. While out of the non-willing respondents $14(82.4 \%)$ were married, $2(11.8 \%)$ were divorced and $1(5.9 \%)$ were widowed. There is statistical significant difference in marital status between willing and non-willing groups $(\mathrm{p}<0.05)$.

Of the total household surveyed $42.2 \%$ have iron roofed house and the rest $57.8 \%$ have grass roofed house. There is statistically significant difference between willing and nonwilling households in terms of their housing type. The education level of the sample respondents was categorized in to those who can read and write as literate and those who cannot read and write as illiterate. Based on this, illiterate respondents constituted 73 $(45.3 \%)$ of the total respondents and the literate groups constituted $88(54.7 \%)$. Out of the willing respondents $62(43.1 \%)$ were illiterate and $82(56.9 \%)$ were literate and the chisquare test depicted that there was statistically $(p<0.1)$ significant difference in education of the household head. Sample respondents who have their own radio were $132(82 \%)$ of the total respondents. Out of this $128(88.9 \%)$ are from willing to pay group, and $4(23.5 \%)$ are from non-willing group. There is also statistically significant difference between the two groups $(\mathrm{p}<0.01)$. The summery of the result is shown below in Table 3 .

Table 3. Characteristics of sample household heads by willing and not-willing groups for (dummy variables)

\begin{tabular}{|c|c|c|c|c|c|c|c|c|}
\hline \multirow[t]{2}{*}{ Variable } & & \multirow{2}{*}{$\begin{array}{l}\text { Willing } \\
\text { to pay } \\
\mathrm{N}\end{array}$} & \multirow[b]{2}{*}{$\%$} & \multirow{2}{*}{$\begin{array}{c}\text { Not-willing } \\
\text { to pay } \\
\mathrm{N}\end{array}$} & \multirow[b]{2}{*}{$\%$} & \multicolumn{2}{|l|}{ Total } & \multirow[b]{2}{*}{$x^{2}$} \\
\hline & & & & & & $\mathrm{N}$ & $\%$ & \\
\hline \multirow[t]{2}{*}{ SEHH } & Male & 141 & 97.9 & 14 & 82.4 & 155 & 96.3 & $10.266^{* * * *}$ \\
\hline & Female & 3 & 2.1 & 3 & 17.6 & 6 & 3.7 & \\
\hline \multirow[t]{4}{*}{ MRST } & Married & 133 & 92.4 & 14 & 82.4 & 147 & 91.3 & $8.876^{* *}$ \\
\hline & Single & 7 & 4.9 & - & - & 7 & 4.3 & \\
\hline & Divorced & 3 & 2.1 & 2 & 11.8 & 5 & 3.1 & \\
\hline & Widowed & 1 & 0.7 & 1 & 5.9 & 2 & 1.2 & \\
\hline \multirow[t]{2}{*}{ HOUSE } & Iron roof & 65 & 45.1 & 3 & 17.6 & 68 & 42.2 & $4.710^{* *}$ \\
\hline & Grass roof & 79 & 54.9 & 14 & 82.4 & 93 & 57.8 & \\
\hline \multirow[t]{2}{*}{ EDUC } & Literate & 82 & 56.9 & 6 & 35.3 & 88 & 54.7 & $2.876^{*}$ \\
\hline & Illiterate & 62 & 43.1 & 11 & 64.7 & 73 & 45.3 & \\
\hline \multirow[t]{2}{*}{ RADIO } & Yes & 128 & 88.9 & 4 & 23.5 & 132 & 82 & $43.983 * * *$ \\
\hline & No & 16 & 11.1 & 13 & 76.5 & 29 & 18 & \\
\hline
\end{tabular}

Source: own survey, 2010

$* * *, * *, *$ Statistically significant at $1 \%, 5 \%$ and $10 \%$ probability levels respectively.

Regarding the continuous variables mean age of the respondent was found to be 39.84 with the minimum 20 and maximum of 71 years. The mean age for willing respondents 
was found to be 40.03 with 20 minimum and maximum of 71 years while that of the nonwilling was 38.29 with minimum of 22 and maximum of 70 years respectively. There is no statistically significant difference between willing and non-willing respondents. The average family size was found to be 5.86 with a minimum of 1 and a maximum of 11 family members. The average family sizes of the willing respondents and non-willing respondents were 6.05 and 4.24, respectively. The result indicates that there is statistically significant difference at $1 \%$ significance level between willing and non-willing respondents in their family sizes $(\mathrm{p}<0.01)$.

Table 4. Characteristics of sample household heads by willing and not-willing groups for (continuous variables).

\begin{tabular}{|c|c|c|c|c|c|c|c|}
\hline Variables & $\begin{array}{l}\text { Willing to } \\
\text { pay } \\
\text { Mean }\end{array}$ & Std. & $\begin{array}{c}\text { Non-willing } \\
\text { to pay } \\
\text { Mean }\end{array}$ & Std. & $\begin{array}{l}\text { Total } \\
\text { Mean }\end{array}$ & Std. & $\mathrm{t}$-value \\
\hline AGE & 40.03 & 11.94 & 38.29 & 14.79 & 39.84 & 12.2 & 0.552 \\
\hline FSIZE & 6.05 & 2.306 & 4.24 & 1.2 & 5.86 & 2.28 & $5.198^{* * *}$ \\
\hline
\end{tabular}

Source: own survey, 2010

*** Statistically significant at $1 \%$ probability level

\section{Resource Ownership}

The survey result showed that income from farm is the main source of subsistence for the majority of the surveyed households. The mean income of the respondents was 7035.40 birr/year with minimum 700 birr/year and maximum of 19,000 birr/year. The mean income of willing and not-willing respondents was 7237.50 birr/year and 5323.53 birr/year, respectively. The result shows that there is statistically significant mean difference between the two groups of the respondents. On the other hand, the mean annual off-farm income of the respondents from different activities was 773.29 birr/year. The corresponding figure for willing respondents was 570.14 birr/year and the mean of non-willing respondents was 2494.12 birr/year. There is statistically significant difference between two groups $(\mathrm{p}<0.01)$.

Table 5. Economic Characteristics of sample household by willing and not-willing groups for (continuous variables)

\begin{tabular}{|c|c|c|c|c|c|c|c|}
\hline Variable & $\begin{array}{c}\text { Willing to } \\
\text { Pay } \\
\text { Mean }\end{array}$ & Std. & $\begin{array}{c}\text { Not-willing } \\
\text { to pay } \\
\text { Mean }\end{array}$ & Std. & Total & Std. & t-value \\
\hline FINC & 7237.5 & 4679.1 & 5323.5 & 4534.4 & 7035. & 5468.7 & 1.600 \\
\hline OFINC & 570.14 & 1376.1 & 2494.1 & 2237.6 & 773.1 & 1595.3 & $-3.469 * * *$ \\
\hline TLU & 7.3141 & 4.4872 & 1.0906 & 3.4249 & 7.693 & 4.5161 & $-3.19 * * *$ \\
\hline
\end{tabular}

Source: own survey, 2010

***, Statistically significant at $1 \%$ level respectively

\section{Institutional characteristics}

Households' institutional characteristics have important effect on the households preferred status with respect to willingness to pay for rainfall risk insurance. The important institutional factors included in the study are: agricultural extension, credit facility, and availability of public and private gifts. 
Of the total households surveyed only $88.8 \%$ had contact with extension agents (Table 6). There was statistically significant difference between the willing and non-willing households in their access to extension services $(p<0.1)$. On the other hand, $28 \%$, the respondents reported to have obtained different public and private aids and the rest $72 \%$ did not have this opportunity. There was also statistically significant difference between willing and non- willing households $(p<0.01)$. About $59 \%$ of the household were reported that they were credit constrained. The result from chi-square test shows there is statistically significant difference between willing and non-willing households in their credit access $(\mathrm{p}<0.05)$.

Table 6. Institutional characteristics of sample households by willing and not-willing groups for (dummy variables)

\begin{tabular}{lcccc}
\hline Variable & $\begin{array}{c}\text { Willingness to pay } \\
\text { Yes }(\%)\end{array}$ & $\begin{array}{c}\text { Not-willing to pay } \\
\text { Yes }(\%)\end{array}$ & $\begin{array}{c}\text { Total } \\
\text { Yes }(\%)\end{array}$ & $\boldsymbol{z}^{2}$ \\
\hline PAPA & 22.9 & 70.6 & 28 & $17.159^{* * *}$ \\
CREDIT & 43.8 & 17.6 & 41 & $4.283^{* *}$ \\
EXTENTION & 90.3 & 76.5 & 88.8 & $2.919^{*}$ \\
\hline
\end{tabular}

Source: own survey

$* * *, * *$, Statistically significantly at $1 \%, 5 \%$ and $10 \%$ level respectively.

An attempt has also been made to compare respondents grouped based on the two survey woredas Dugda and Mieso among dummy and continuous variables. Table 7 presents the summary of the descriptive statistics.

Table 7. Summary of descriptive statistics of sample households' characteristics by woreda for (continuous variables).

\begin{tabular}{lllllc}
\hline & \multicolumn{2}{c}{ Dugda } & \multicolumn{2}{c}{ Misso } & t-value \\
Variables & mean & Std. & mean & Std. & \\
\hline AGE & 41 & 13.1 & 38 & 10.5 & $1.639^{* *}$ \\
FINC & 6764 & 4643 & 7480 & 4763.9 & -0.940 \\
OFINC & 721 & 1475.8 & 859 & 1783.5 & -0.531 \\
FSIZE & 6.25 & 2.5 & 5.21 & 1.704 & $3.125^{* * *}$ \\
TLU & 7.76 & 4.52 & 7.58 & 4.545 & 0.243 \\
\hline
\end{tabular}

Source: survey result (2010)

$* * * * *$ Statistical significant at $1 \%$ and $5 \%$ probability level.

The purpose of these comparisons using descriptive statistics by woreda was to examine whether there is significant difference between the two woredas in terms of household characteristics, institutional factors and resource ownership. The above Table (Table 7) presents the mean comparison of continuous variables between two woredas. Age of the household head and family size were found to be statistically significant at $5 \%$ and $1 \%$ significant levels respectively. On the other hand no statistically significance difference was observed between the two woredas in terms of total income from crop, total off-farm income and total livestock holding.

Summary of descriptive statistics for dummy variables presented in Table 8 also depicts that there is statistically significant difference at less than $1 \%$ significant level in two 
woredas of the study area includes: sex of the household head, marital status of the household head, education of the household head, housing type, access to extension services, owning radio and credit constraint. But there is no statistically significant difference in availability of public and private aid in between two woredas.

Table 8. Summary of descriptive statistics of sample household characteristics by woredas for (dummy variables).

\begin{tabular}{|c|c|c|c|c|}
\hline \multirow[b]{2}{*}{ Variable } & & Dugda & Mieso & \multirow{2}{*}{$x^{2}$} \\
\hline & & $\mathrm{N}$ & $\mathrm{N}$ & \\
\hline \multirow[t]{2}{*}{ SEHH } & Male & 100 & 55 & $10.217^{* * * *}$ \\
\hline & Female & - & 6 & \\
\hline \multirow[t]{4}{*}{ MART } & Married & 94 & 53 & $13.343^{* * * *}$ \\
\hline & Single & 6 & 1 & \\
\hline & Divorced & - & 5 & \\
\hline & Widowed & - & 2 & \\
\hline \multirow[t]{2}{*}{ EDUC } & Literate & 68 & 20 & $18.957^{* * * *}$ \\
\hline & Illiterate & 32 & 41 & \\
\hline \multirow[t]{2}{*}{ HOUSE } & Iron roofed & 55 & 14 & $17.625^{* * *}$ \\
\hline & Grass roofed & 45 & 48 & \\
\hline \multirow[t]{2}{*}{ EXTENTION } & Yes & 95 & 48 & $10.152^{* * *}$ \\
\hline & No & 5 & 13 & \\
\hline \multirow[t]{2}{*}{ PAPA } & Yes & 29 & 16 & 0.144 \\
\hline & No & 79 & 45 & \\
\hline \multirow[t]{2}{*}{ RADIO } & Yes & 89 & 43 & $8.788^{* * *}$ \\
\hline & No & 11 & 18 & \\
\hline \multirow[t]{2}{*}{ CREDIT } & Yes & 58 & 8 & $31.557^{* * * *}$ \\
\hline & No & 42 & 53 & \\
\hline
\end{tabular}

Source: survey result (2010)

*** Statistically Significant at 1\% Probability level.

\section{Sources of Risk and Management Strategies Practiced}

Farmers were highly affected by many sources of risk, but they were trying to cope and live with these risks. Households in the study areas were also practicing different mechanisms in order to make their living. Among many sources of risk, the following were identified as the major ones by respondents. Households were asked to list the most important, second most important and the third most important sources of risk that they faced. Responses were classified into the categories listed below. 
Table 9. Major sources of risk as perceived by sample respondents and their rank given by sample households

\begin{tabular}{lccc}
\hline Sources of risk & $1^{\text {st }}$ & Rank (=161) & $2^{\text {nd }}$ \\
\hline Drought/erratic rainfall & 156 & 10 & 18 \\
Crop disease & 1 & 128 & 66 \\
Loss of livestock & 1 & 6 & 2 \\
Loss of fertility of the soil & 2 & 8 & 71 \\
Price variability & 1 & 7 & 2 \\
Low market demand & - & 1 & 2 \\
Fire & - & - & - \\
Flood & - & 1 & -
\end{tabular}

Source: own survey, 2010

Table 9 shows, clearly that the most important source of risk identified by the respondents was drought or erratic rainfall. The second was crop failure due to crop diseases and the third reason was loss of fertility of the soil. Therefore, Drought was the major source of risk in the study area.

\section{Risk management strategies}

In order to cope with sources of risks below in table 10, rural households have developed through time various risk management strategies which only differ from place to place, and among the farmers. Farmers in the study area practice sale of livestock as a major risk coping strategy. Diversification, use of improved technology, delay in sale of crop and intercropping were also strategies used by farmers. There is statistically significant difference in coping strategies between willing and non-willing respondents in terms of diversification, off-farm employment and use of improved technologies. But there is no statistically significant difference in terms of intercropping, go for credit, delay in sale of crop and sale of livestock.

Table 10. Risk management strategies practiced by sample households

\begin{tabular}{lccl}
\hline & $\begin{array}{c}\text { Willingness to } \\
\text { pay }\end{array}$ & $\begin{array}{c}\text { Not-willing to } \\
\text { pay }\end{array}$ & $\mathcal{X}^{2}$ \\
\cline { 2 - 4 } Management strategies & Yes (\%) & Yes (\%) & \\
\hline Intercropping & 66.7 & 76.5 & 0.668 \\
Diversification & 81.9 & 64.7 & $2.837^{* * *}$ \\
Off-farm income & 11.8 & 70.6 & $35.58^{* * *}$ \\
Go for credit & 75.5 & 58.8 & 0.279 \\
Delay sale of crop & 2.1 & - & 2.244 \\
Contract sale & 80.6 & 52.9 & 0.3461 \\
Use of improved technology & 85.4 & 88.2 & $6.679^{* * *}$ \\
Sale of livestock & 85.4 & 29.4 & 0.099 \\
\hline
\end{tabular}

Source: own survey, 2010

***, significant at $1 \%$ 


\section{Risk perception of sample households}

Households in the study area perceive that they are exposed to different types of substantial risks from different sources. Therefore, based on the results obtained from formal survey questionnaire, households define risk in three ways: year when rainfall delays, year when rainfall is inadequate, year when rainfall is high. The summary of the result are presented and discussed below in Table 11.

Table 11. Definition of risk by sample households

\begin{tabular}{lllcc}
\hline Description & Willing & \multicolumn{3}{c}{ Not-willing } \\
\cline { 2 - 5 } & $\mathrm{N}$ & $\%$ & $\mathrm{~N}$ & $\%$ \\
\hline Year when rainfall delays & 27 & 18.7 & - & - \\
Year when rainfall is low & 116 & 80.6 & 17 & 100 \\
Year when rainfall is high & 1 & 0.7 & - & - \\
\hline Total & $\mathbf{1 4 4}$ & $\mathbf{1 0 0}$ & $\mathbf{1 7}$ & $\mathbf{1 0 0}$ \\
\hline
\end{tabular}

Source: survey data, 2010

Out of the total households surveyed $80.6 \%$ define risk as a situation where the expected rainfall is low. The others $18.7 \%$ and $0.7 \%$ percent of the sample households define it as the situation when the rainfall delays and the expected rainfall is high, respectively. Similarly, when the households were asked which was the most risky year in the ten years preceding survey, $105(65.2 \%)$ of the sample households reported the year 2001 the others $47(29.2 \%), 3(1.9 \%), 2(1.2 \%)$ identified the years 1995, 2000 and 1994, respectively.

Out of the willing respondents 131 (91\%) showed their interest to pay the premium in cash and the remaining $13(9 \%)$ in kind. The respondents also discussed about the time of insurance premium payment. Of the willing respondents, $129(89.6 \%)$ reported that the preferred to pay after the time of harvesting. Their main reason stated for this preference was the prospects of earning money after harvest by selling what they produced. Ninety four $(65.28 \%)$ of the respondent choose the indemnity to be paid in cash, because they need the money to buy better improved varieties, water pump (hand pump), implement and engaged in fattening activities etc. The other fifty (34.72\%) stated that they would opposite for the payment in kind because they are afraid of losing the money without any activity, so that they prefer only the lost product or grain.

\section{Willingness to Pay Analysis}

Before implementing the final survey, the pilot survey was conducted using open-ended elicitation format to set up starting bid. The bid values were 50, 100, 150 and 200 based on the pilot survey. The follow-up question was open-ended; if the respondent answered "no" to the randomly aligned initial bid, he/she was then asked how much he/she would pay for the service. If the respondent answered "yes" to th e randomly aligned initial bid, he/she was then asked what was the most he/she would pay for the service.

The total sample households were randomly distributed to the four initial bid value groups and each contains 41, 47, 36 and 37 respectively. Out of the total sample respondents $17(27.2 \%)$ responded "no" to the initial bid value. The main reason they have stated includes mainly they couldn't afford it, and they didn't trust the service. But the rest $144(72.8 \%)$ show their interest to contribute and gave the "yes" or "no" response to the initial bid value then follow up values. 
Table 12. Maximum WTP and percentage distribution of the sample household

\begin{tabular}{lcc}
\hline $\begin{array}{l}\text { Maximum WTP } \\
\text { Birr/hectare }\end{array}$ & $\begin{array}{c}\text { Number of } \\
\text { respondents }\end{array}$ & $\begin{array}{c}\text { Percentage of the } \\
\text { Respondents }\end{array}$ \\
\hline $0-50$ & 39 & 24.3 \\
$51-100$ & 54 & 33.6 \\
$101-150$ & 11 & 6.8 \\
$151-200$ & 37 & 23 \\
$201-250$ & 7 & 4.3 \\
$251-300$ & 7 & 4.3 \\
$301-350$ & 5 & 3.1 \\
$351-400$ & 1 & 0.6 \\
\hline Total & 161 & 100 \\
\hline
\end{tabular}

Source: own survey, 2010

\section{Estimation of the mean WTP value}

The initial bid value was regressed with the dependent dummy variable, the result of the coefficients were presented in Table 13, and mean willingness to pay for the single bounded dichotomous format is as follows.

Table 13. The Logit model to calculate the mean WTP

\begin{tabular}{lcccc}
\hline Variables & Coefficient & St. d & t-value & p-value \\
\hline CONST & 3.993626 & 0.6619955 & 6.03 & 0.0000 \\
BID & -0.021873 & 0.0042091 & -5.20 & 0.0000 \\
\hline
\end{tabular}

$\mathrm{E}(\mathrm{WTP})=\frac{\operatorname{lu}\left(\boldsymbol{1}+\exp \left(\beta_{0}\right)\right)}{\beta_{1}}$

Where:

$$
\beta_{1}=0.021873
$$

$$
\begin{aligned}
\beta_{0} & =3.993626 \\
& =\frac{\ln (\mathbf{1}+\exp (\mathbf{3} .993626))}{\mathbf{0 . 0 2 1 8 7 3}}=183.41
\end{aligned}
$$

Thus the mean willingness to pay calculated from the single bounded dichotomous format is 183.41 birr per hectare. However, the mean WTP is 129.93 birr per hectare from responses to the open-ended CV survey questions, which is lower than the mean value obtained from the closed-ended Logit model estimates. Thus the result showed that the respondents were willingness to pay between the ranges of 129.93-183.41 Birr per hectare for the proposed rainfall based insurance service.

\section{Estimating total willingness to pay and total revenue}

In this section the total willingness to pay and total revenue at different prices that households in the seven PAs of the two woredas (Dugda and Mieso) were willing to pay 
as computed. The sampled seven PAs namely, (B/Gusaa, Odd Bokota, Jawe Bofo, S/wakalee, Huse mandhera, Chobi, Burimulu) have a total of 3281 households with a total population of 49,966 households with a total population of 275,307 and an average family size of 5.86. Based on this information and the distribution of WTP amount by the respondents, it would be possible to estimate the expected total willingness to pay and total revenue for the study area. Table 14 provides the procedure and results from this analysis.

Table 14. Total willingness to pay and total revenue in (Birr)

\begin{tabular}{|c|c|c|c|c|c|c|c|c|c|}
\hline \multirow[t]{2}{*}{$\begin{array}{l}\text { Class bound. } \\
\text { For WTP } \\
\text { amount }\end{array}$} & \multirow{2}{*}{$\begin{array}{l}\text { Class } \\
\text { mark for } \\
\text { WTP } \\
\text { amount }\end{array}$} & \multicolumn{2}{|c|}{$\begin{array}{l}\text { Sample } \\
\text { District of } \\
\text { HHs }\end{array}$} & \multirow[t]{2}{*}{$\begin{array}{l}\text { Total no of } \\
\text { HHs }\end{array}$} & \multirow[t]{2}{*}{ Total WTP in Birr } & \multicolumn{2}{|c|}{$\begin{array}{l}\text { Sample HHs WTP } \\
\text { at least that } \\
\text { amount }\end{array}$} & \multirow{2}{*}{$\begin{array}{l}\text { Total HHs } \\
\text { WTP at } \\
\text { least that } \\
\text { amount }\end{array}$} & \multirow[t]{2}{*}{ Total Revenuc } \\
\hline & & $\mathrm{N}$ & $\%$ & & & $\mathrm{~N}$ & $\%$ & & \\
\hline $0-50$ & 25 & 39 & 24.223 & $12,103.3$ & 302,582 & 161 & 100 & 49,966 & $1,249,150$ \\
\hline $51-100$ & 76 & 54 & 33.54 & \begin{tabular}{|l|}
$16,759.6$ \\
\end{tabular} & $1,273,729$ & 122 & 75.78 & 37,864 & $2,877,664$ \\
\hline $101-150$ & 126 & 11 & 6.832 & $3,414.18$ & 430,186 & 68 & 42.24 & 21,105 & $2,659,230$ \\
\hline $151-200$ & 176 & 37 & 22.981 & 11482.7 & $2,020,953$ & 57 & 35.40 & 17,688 & $3,113,088$ \\
\hline $201-250$ & 226 & 7 & 4.347 & $2,172.02$ & 490,877 & 13 & \begin{tabular}{|l|}
8.07 \\
\end{tabular} & 4032 & 911,232 \\
\hline $251-300$ & 276 & 7 & 4.347 & $2,172.02$ & $\begin{array}{l}599,478 \\
\end{array}$ & 11 & 6.83 & 3413 & $\begin{array}{l}941,988 \\
\end{array}$ \\
\hline $301-350$ & 326 & 5 & 3.105 & 1551.44 & 505,771 & 6 & 3.73 & 1864 & 607,664 \\
\hline $351-400$ & 376 & 1 & 0.621 & 310.29 & 116,669 & 1 & 0.62 & 310 & 116,560 \\
\hline Total & & 161 & 100 & 49,966 & $5,740,244$ & & & & \\
\hline
\end{tabular}

Source: Own survey, 2010

The first column shows the maximum willingness to pay interval, and the second is class mark for willingness to pay (the mid willingness to pay amount) of the first column. The third and the fourth columns show the number and the percentage of sample households whose willingness to pay amount falls within the given interval.

The total number of households in two woredas of the study area has been multiplied by the proportion of sample households falling in each category to obtain the total number of households whose willingness to pay amount lies in each boundary (column fifth). And total willingness to pay (column sixth) has been obtained by multiplying the mid willingness to pay amount by total number of households willingness to pay that amount. The total household of 49,966 in two woredas of the study area were expected to pay birr $5,740,244$ per year, if every household insures one hectare of his land.

Therefore, the result of the survey indicates that the average insurance premium payment of household was birr 114.88 per hectare per household if the proposed insurance service is implemented. This result is almost similar with the average willingness to pay of 129.93 birr per household per hectare. A column seven and eight indicates the number and the percentage of sample household willingness to pay at least the amount in each interval. Similarly, column nine shows total number of households willing to pay at least the amount in each interval and it falls as the mid willingness to pay amount rises (column ten). Total revenue has been obtained by multiplying the mid willingness to pay amount (column two) by the corresponding total number of households' willingness to pay at least that amount, (column nine). 


\section{Derivation of aggregate demand}

The aggregate demand for this study has been derived from the above willingness to pay scenario (Table 14). The aggregate demand curve is derived using the mid willingness to pay amount along the vertical axis and the number of households' willingness to pay at least that mid value per hectare along the horizontal axis, (Figure 2). The figure shows the aggregate demand curve for the rainfall based insurance using the observations in the study. Any point on the curve shows all the households that prefer the insurance service but do not bid more than the corresponding value on the mid willingness axis.

As shown in Figure 2, the demand curve is negatively sloped, indicating the fall of the demand for the insurance service as the premium increases, like most other non-market goods other things remaining constant. The area under demand curve represents the gross value of consumers' surplus if the service is available for free or zero.

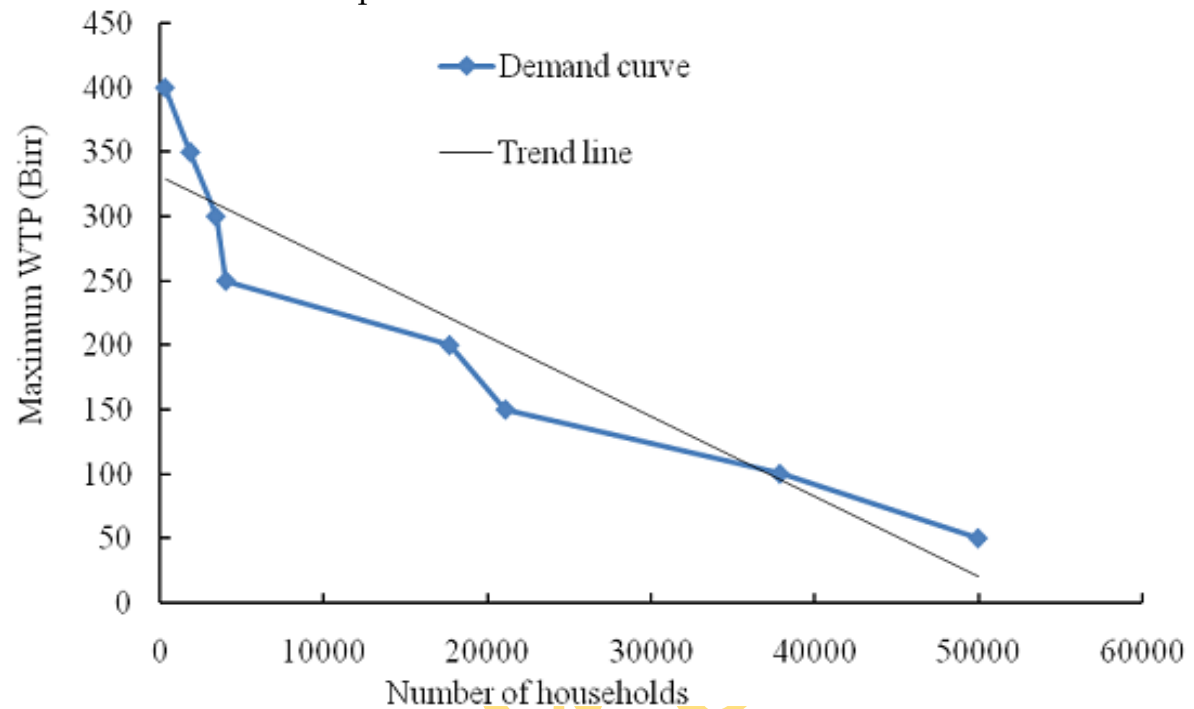

Figure 2. Estimated demand curve for rainfall based insurance service

\section{Econometric Model Result}

Econometric software called Limited dependant (Limdep 7) was employed to estimate the Tobit model. In the tobit model the main objective is to identify factors affecting the willingness to pay for rainfall risk insurance and its intensity in relation to socio-economic and demographic variables.

\section{Econometric test and results}

Before taking explanatory variables in to the analysis, it was necessary to check the existence of multicolinarity among the continuous and dummy variables. Variance inflation factor (VIF) was used to detect mulitcollinarity among continuous variables and contingency coefficient $(\mathrm{C})$ was used to detect the degree of association among dummy variables. According to Maddala (1992), VIF can be defined as:

$$
\operatorname{VIF}\left(x_{t}\right)=\frac{1}{1-R^{2}}
$$

Where, $R^{2}$ is the squared multiple correlation coefficient between $x i$ and other explanatory variables. A statistical package known as SPSS 16 was used to compute the VIF values. As a rule of thumb, when the VIF exceeds 10, there is muliticollinarity problem. VIF values 
shown in the Appendix Table 1 indicate that there was no serious muliticolinarity problem. Similarly, contingency coefficients were used to check the existence of muliticolinarity. Contingency coefficient is computed as follows:

$$
C=\sqrt{\frac{z^{2}}{N+Z^{2}}}
$$

Where:

$$
\begin{gathered}
C=\text { is coefficients of contingency } \\
x z=\text { chi-square random variable }
\end{gathered}
$$

$N=$ total sample size

The rule of thumb for Contingency coefficient is that when its value approach as 1 and greater than 0.75 there is muliticolinarity problem between dummy explanatory variables. But the result shown in the Appendix Table 2 revealed that all values were less than 0.75 and there was no serious muliticolinarity problem among dummy variables.

The assumption in regression analysis is that the errors terms, Ui has a constant variance $\delta^{2}$. If the error term doesn't have a constant variance, there is problem of hetroscedastics (Maddala 1992). In the general linear model, OLS estimates are consistence but not efficient when the disturbance terms are hetroscedastic. In the case of limited dependent variable models (such as Tobit), the estimates of the corresponding regression coefficient is upward biased in the presence of hetroscedasticity. But nothing can be said about the direction of bias. It is more practicable to make some reasonable assumption about the nature of hetetroscedasticity and estimate the model to say that the maximum likelihood estimates are inconsistent if hetroscedasticity is ignored (Maddal 1992). The test for the presence of heteroscedasticity problem in the model was also done by using BreuschPagen test and the result was $\rho=1.250$, this shows that there is no heteroscedasticity problem in the model.

\section{Interpretation of the results}

The estimates of the parameters of the variables that were expected to affect the households' willingness to pay for rainfall based insurance are shown in Table 15. The dependent variable was a continuous variable that household response as maximum willingness measured in birr. Out of the 16 hypothesized explanatory variables, six were found to be statistically significant, four of them were continuous and the rest two were dummy variables. The variables were age of the household head (AGE), total income from farm (FINC), total off-farm income (OFINC), livestock holding (TLU), owning radio (RADIO), and availability of public and private aid (PAPA). Moreover, the sign of the estimated coefficients were consistent with the expected signs.

The result has shown that age of household (AGE) is an important factor that influences the respondent's willingness to pay negatively and it is statistically significant $(\mathrm{p}<0.05)$. Earlier studies by Patrick (1988) and Gine et al. (2007) have found similar results. As the age of household head increases, the willingness to pay amount decreases significantly. Therefore, younger household heads are more likely to be willing to pay for rainfall based insurance compared to older household heads. This may be explained by the fact that younger household heads have less long life experience on predicting weather conditions and they are also sensitive to the new technologies than elders. The result shows that for each additional year in age of the respondent, the probability of the willingness to pay for rainfall based insurance decreases by $0.548 \%$. The marginal effect result also shows that as 
the age of a respondent increase by one year, the amount of cash s/he is willing to pay for rainfall based insurance decreases by 1.5159 Birr.

Household income from crop (FINC): This variable is found to have a positive impact on the probability of willingness to pay as hypothesized and the effect is statistically significant at $1 \%$ probability level. Those household heads that generate high income from crop production would be more willing to pay for rainfall based insurance. When the income of the household increases by one birr, the probability of the household to be willingness to pay for rainfall based insurance increases by $0.002 \%$. The marginal effect result shows that when the income level of the household increase by one Birr, the amount of cash the household could pay for rainfall based insurance increases by 0.0055 Birr, other factors held constant at their mean values.

Ownership of radio by the household (RADIO) is another important factor which is positively and significantly $(\mathrm{p}<0.05)$ related to farmers' willingness to pay for rainfall based insurance and its amount. Information from radio enhances the ability of farmers' access to improved technologies and risk management strategies. Farmers that own radio may get different information on extension service, credit service, improved seed variety, input prices and output prices than those farmers who do not have radio. This variable also shows that farmers that own radio have $15.218 \%$ more probability of paying for rainfall based insurance than those farmers who do not possess. Also, the marginal effect of this variable shows farmers that own radio, would pay Birr 42.0637 more than those farmers that do not have radio.

As expected the availability of off-farm income (OFINC) is negatively and significantly related to willingness to pay $(\mathrm{p}<0.05)$. Households engaged in off-farm activities reduce the probability of willingness to pay for rainfall based insurance by $0.003 \%$. Households who are engaged in off-farm activity are expected to have less attention to farm activity. Sukurai and Reandon (1997) have found similar result. The marginal effect of this variable also shows when off-farm income increases by one Birr the amount of cash households would be willing to pay for rainfall based insurance decreases by 0.0098 Birr, other factors held constant.

Public and private gift (PAPA): This is another important factor which affects the dependent variable negatively and significantly $(p<0.01)$. Availability of public and private aid decreases the willingness to pay by $16.233 \%$. Sukurai and Reandon (1997) have found a negative effect on the dependent variable when farmers have aid from governmental or other non-governmental organizations, either in kind or in cash, and this may be explained by the fact that as households become more dependent and less active, and their willingness to pay tends to be less. The marginal effect of the variable shows that those household who have some kind of public and private gifts decrease willingness to pay amount by 44.8686 Birr than those who don't have the gift, other variables held constant.

Livestock Holding (TLU): Number of livestock owned by households is found to have negative and significant $(\mathrm{p}<0.01)$ effect on willingness to pay. Each additional unit of livestock (TLU) decreases the willingness to pay by $1.618 \%$. This implies that income from livestock may encourage farmers to depend more on livestock than farming and results in less attention being give to the crop production. The marginal effect shows that for each additional TLU that the household possess the willingness to pay amount decreases by 4.4728 Birr, other variables held constant. 
Asia Pacific Journal of Energy and Environment, Volume 1, No 2 (2014) 
Asia Pacific Journal of Energy and Environment, Volume 1, No 2 (2014)

Table 15. Maximum Likelihood estimates of the Tobit model

\begin{tabular}{lccc}
\hline Variables & Estimated coefficient & Standard error & t-ratio \\
\hline Constant & 3.70112 & 103.639 & 0.0357 \\
NAWO & -2.77379 & 18.8725 & -0.14697 \\
SEHH & 105.47 & 62.4742 & 1.68821 \\
AGE & -1.72656 & 0.71336 & $-2.42032^{* *}$ \\
EDUC & 7.89432 & 15.9354 & 0.49539 \\
MRST & 22.2316 & 22.1423 & 1.00403 \\
FINC & 0.00556 & 0.00155 & $3.59743^{* * *}$ \\
OFINC & -0.01032 & 0.00487 & $-2.12119^{* *}$ \\
DEPR & -0.66475 & 8.84637 & -0.07514 \\
FSIZE & 5.18168 & 3.7561 & 1.37954 \\
TLU & -5.01802 & 1.64755 & $-3.04575^{* * *}$ \\
CREDIT & -9.49309 & 15.8865 & -0.59756 \\
EXTENTION & 24.4899 & 22.8428 & 1.0721 \\
PAPA & -49.3245 & 16.0296 & $-3.0771^{* * *}$ \\
BID & 0.05866 & 0.12318 & 0.47623 \\
RADIO & 33.4783 & 20.6775 & $1.61906^{* *}$ \\
HOUSE & 0.68939 & 14.8145 & 0.04653 \\
NUmber & & &
\end{tabular}

Number of observation $=161$

Log likelihood $=-854.3120$

Threshold value for the model: Lower $=0.0000$

Upper $=+$ infinity

$\delta=83.4523$

$\underline{Z}=1.48 \quad \phi(\mathrm{z})=0.2859 \quad \Phi(\mathrm{z})=0.9307$

$* * *, * *, *$ indicate significance at $1 \%, 5 \%$, and $10 \%$ levels, respectively Source: model result, 2010

Table 16. Marginal effects of the explanatory variable on the dependent variable

\begin{tabular}{|c|c|c|c|}
\hline Variables & $\begin{array}{l}\text { Change in probability } \\
\qquad \frac{\partial F(\boldsymbol{z})}{\theta X t}\end{array}$ & $\begin{array}{l}\text { Change among willing } \\
\qquad \frac{\Delta E\left(\frac{y l}{\gamma_{l}} ; 0\right)}{\partial \times t}\end{array}$ & $\begin{array}{l}\text { Total change } \\
\frac{\partial E(y t)}{\partial X t}\end{array}$ \\
\hline NAWO & -1.66800 & -2.63030 & -2.58250 \\
\hline SEHH & 63.4230 & 100.0140 & 98.1955 \\
\hline AGE & -0.00548 & -1.51590 & -1.4900 \\
\hline EDUC & 0.04564 & 12.6173 & 12.4022 \\
\hline MRST & 13.3687 & 21.0861 & 20.6982 \\
\hline FINC & 0.00002 & 0.0055 & 0.0054 \\
\hline OFINC & -0.00003 & -0.0098 & -0.0096 \\
\hline DEPR & 0.01727 & -4.7743 & -4.6929 \\
\hline FSIZE & 0.01691 & 4.6763 & 4.5966 \\
\hline TLU & -0.01618 & -4.4728 & -4.3966 \\
\hline CREDIT & 0.02439 & -6.7416 & -6.6269 \\
\hline EXTENTION & 0.09502 & 26.2641 & 25.8164 \\
\hline PAPG & -0.16233 & -44.8686 & -46.723 \\
\hline BID & 0.00085 & 0.0235 & 0.0231 \\
\hline RADIO & 0.15218 & 42.0637 & 41.4367 \\
\hline HOUSE & 0.01919 & 5.3063 & 5.2159 \\
\hline
\end{tabular}

Source: based on model out put 


\section{Summary and Policy Recommendations}

\section{Summary and Conclusion}

The main objective of this study was to identify factors affecting smallholder farmers' willingness to pay for rainfall based insurance in Central rift valley of Ethiopia. The study was designed to identify the variables, which determine farmers' willingness to pay for rainfall based insurance. This study tried to look in to socio economic, institutional and physical and other related factors which can affect farmers' willingness to pa y for rainfall based insurance. Data were collected from 161 farm households drawn randomly from Dugda and Mieso Woredas. The primary data were collected using semi structural questionnaire and the secondary data were obtained from woredas agricultural office and other non-governmental organizations around the woredas. Both descriptive statistics and econometric model were employed to analyze the data. Contingent Valuation Method (CVM) was employed to elicit farmers WTP for rainfall based insurance. The responses from the survey were analyzed by using economic software Limdep version 7.

Descriptive statistics were also used to describe risks faced by smallholders' farmers and management strategies practiced by the respondents. It also shows that there were significant differences between willing and non-willing households with respect to some variables of interest which include: sex, marital status, house type, education, owning radio, off-farm income, income, family size, credit constraint, availability of public and private aid and access to extension service at different significant levels.

The result from descriptive statistics also revealed that households suffered from drought or erratic rainfall, crop disease and loss of fertility of soil respectively. Therefore, they have practiced different types of coping strategies which included: intercropping, diversification, off-farm employment, go for credit and delay in sale of crop. The study used CVM technique to elicit farmers' willingness to pay for the proposed rainfall based insurance service. The sampled households were asked questions, related to their socio economic, demographic, institutional characteristics and some general questions. They were also asked dichotomous question and this were followed by open ended question to elicit households' willingness to pay for the proposed rainfall based insurance service. Of the total sample households 144 $(89.4 \%)$ were willing to participate and the rest $17(10.6 \%)$ were not willing to participate. The following bid values 50, 100, 150 and 200 were found from the first open-ended questions. The total willingness to pay amount for the total of 49,966 households is estimated to be birr 5, 740,244 per hectare per year. Sixteen potential explanatory variables were hypothesized to explain farmers' willingness to pay for rainfall risk insurance, and they were measured based on the model output. The result of Tobit model revealed that only six potential explanatory variables were used to identify willingness to pay among selected sample households at different significant levels. Among the six potential explanatory variables, three were significant at $1 \%$ probability level and the other three were found to be significant at $5 \%$ probability level to willingness to pay. Age of the household was found to have a negative and significant impact on farmers' willingness to pay for rainfall risk insurance at $(p<0.05)$ level it implying that aged farmers' have confident by their own weather condition prediction trend from their long life experience and they may not trust the insurance service. But younger farmers could easily decide to take part willingly in proposed insurance service.

Income from crop production was another important, highly significant and positively related variable that affect willingness to pay for the proposed insurance service at $1 \%$ probability level. Households with more income from their crop production could be willing to contribute more of their income for the proposed rainfall based insurance service. This means that income is an important variable affecting the willingness to pay. Households' off-farm income is also another significant and important variable which is found to be negatively related to the willingness to pay for the rainfall based insurance 5\% probability level. The result revealed that 
households with radio have more information access on different aspects of both agricultural and non-agricultural sectors. This variable was positively related to willingness to pay at $5 \%$ probability level. This means willingness to pay for the rainfall risk insurance is more related to both information access and awareness. Availability of public and private aid was found to be highly significant at $1 \%$ probability level and it was negatively related to the willingness to pay. Households who are more dependent on governmental and non-governmental organizations aids are not willing to pay for the proposed rainfall based insurance service payment. The last important variable is households' livestock holding it was found to be negatively related to willingness to pay at $1 \%$ probability level. This is also because of households with more livestock number depending more on the livestock production as their primary activity and may have less time to care the crop production activity.

\section{Policy Implication of the Study}

The overall understanding of factors affecting smallholder farmers' willingness to pay for rainfall based insurance would help policy makers and development workers to design and implement the rainfall based insurance service in sustainable and in effective manner. Based on the findings of the study, the following points are suggested to be considered as an important element in order to implement the service and enhance farmers' rainfall based insurance utilization and effectiveness in the country.

The strong negative relation between availability of public and private aid and willingness to pay for the proposed rainfall based insurance revealed that in order to increase the willingness of household, development policies focused on sustainable development rather than giving some aid at the time when disaster is occurred. This can be through organizing farmers in to saving and credit cooperatives so that they can increase their income and can be self sufficient.

Household income from crop and willingness to pay for rainfall based insurance were positively related, development policies should target at increasing income of households that address specially the low income members of the smallholder farmers. This can also be through facilitating and forming small business groups, educating and giving awareness to involve in credit and saving cooperatives.

Household off-farm income and willingness to pay for rainfall based insurance were negatively related. Household willingness to pay for rainfall based insurance were relatively less if they have off-farm income from other non-farm related activities this is because of off-farm income is another option for households' livelihood.

Households who have radio have an access to information as well as they have awareness on different agricultural activities such as market price, post harvest management strategies, and information on weather conditions. Development policies focused on the different Medias to create awareness and understanding among farmers.

\section{REFERENCES}

Addis Ababa University, 2001. Introductory geography of Ethiopia Geo,101. Teaching text, Department of Geography.

Alberini, A., and Cooper, J., 2000. Application of contingent valuation method in developing countries. Economic and social development paper. No. 146, FAO, Rome.

Anderson, D.R., 2001. All Risks Rating Within a Catastrophe Insurance System. Journal of Risk and Insurance. 43: 629-651.

Anderson, J. R., Dillon,J. L., and Hardaker, J.R., 1977. Agricultural decision analysis: Lowa State University press.

Assefa Demeke and G. Ramakrishna, 2002. An empirical analysis of food security in Ethiopia, the 
Asia Pacific Journal of Energy and Environment, Volume 1, No 2 (2014)

case of North Wollo. African Development Journal. 27 (1\&2):127-144.

Bateman, I. J. H. Langford, A. P. Junes, G. B. Kerr and R. Scarpa, 2000. Bound and path effects in double and triple bounded dichotomous choice contingent valuation. A paper presented at the tenth annual conference of the European Association of Environmental Resources Economists (EAERE), Great Britain.

Binswanger, H.P., 1980. Attitudes towards risk. Experimental measurement in rural India. American Journal of Agricultural Economics. (62): 395-407.

Bryan, E., T. Deressa, G. Gbetibouo and C. Ringler (2009). Adaptation to climate change in Ethiopia and South Africa: options and constraints. Environmental Science and Policy, 12: 413-426.

Carson, R.T., 1991. Constructed Markets. In: J.Barden and C.Kolstad (eds). Measuring the Demand for Environmental Commodities. Amsterdam, North Holland.

Carson, R.T., N.E. Flores and N.F. Meade, 2001. Contingent Valuation: Controversies and Evidence. Environmental and Resource Economics, 19(2): 173-210.

Cooper, J. and T. Osborn, 1998. The Effect of Rental Rates on the Extension of Conservation Reserve Program Contracts. American Journal of Agricultural Economics 80, 184-194.

CSA (Central Statistics Authority), 2004. Agricultural sample survey report Federal Democratic Republic of Ethiopia, Addis Ababa, Ethiopia.

Dandekar, V.M. 1977. Crop insurance for developing countries. Teaching and Research Forum Paper No. 10. New York: Agricultural Development Council.

Dennis Holden, Peter Hazell, Anthony Pritchard, 1991. Risk in Agriculture. Proceedings of the Tenth Agriculture Sector Symposium. World Bank Washington, D.C. USA.

Dillon J.L and J.B. Hardaker, 1993. Farm management research for small farmers development. FAO Farm Management Series. FAO, Roma Italy. (6):302

Freeman, A.M., 2003. The Measurement of Environmental and Resource Values: Theory and Methods. Washington, D.C.

Gautam, M., Hazell, P., and H. Alderman, 1994. Rural demand for drought insurance, world bank Policy Research Working Paper No. 1383.

Gine Xavier, Robert Towensend and James Vickery, 2007. Patterns of rainfall insurance participation in rural India, Policy research working paper. 4408.

Greene, W. H., 2003. Econometric Analysis. Fourth Edition, Prentice Hall International, Inc. USA.

Gujarti, D., 1999. Essential of Econometrics. Second edition, Mc-Graw hill companies.

Halcrow, H.G. 1948. The theory of crop insurance. Ph.D. diss. Chicago: University of Chicago.

Hanemann, W.M., 1991. Willingness to accept and willingness to pay and how much can they differ? American Economic Review, 81(3): 635-647.

Hanemman, W.M \& Kanninen. B., 1998. The statistical analysis of discrete response data. Department of Agricultural, Resource Economics and Policy, Working paper No, 798 University of California, Berkeley.

Hardaker, J. Banri., Ruud B.M. Hurnie and Jock R.Anderson, 1997. Coping with risk in agriculture. CAB International London.1-10p.

Hauseman, J., 1993. Contingent Valuation: A critical Assessment, North Holland Publishing Co., Amsterdam.

Hazell, P, J. Anderson, N.Balzer, A.Hustarp Celmmensen, U.Hess and F.Rispoli. 2010.

Hazell, P.B.R., 1992. The appropriate role of agricultural insurance in developing countries. Journal of International Development. (4):567-581.

Hellmuth M.E., Osgood D.E., Hess U., Moorhead A. and Bhojwani H (eds), 2009. Index insurance and climate risk: Prospects for development and disaster management. Climate and Society No. 2. International Research Institute for Climate and Society (IRI), Colombia University, New York, USA.

IAC. 1986. Crop and rainfall insurance. Report No. 393. Canberra: published for the Industries Assistance Commission by the Australian Government Publishing Service.

IPMS (Improving Productivity and Market Success), 2006. Pilot searing site of Mieso woreda. IPMS, Adiss Ababa, Ethiopia. http//www. IPMS-Ethiopia.org.

Long, S., 1997. Regression Models for Categorical and Limited Dependent Variables. Saga Publications. 
Maddala, G.S., 1992. Introduction on Econometric. Second edition . Macmillan Publishing Company, New York.

Maddala, G.S., 1997. Limited Dependent and Qualitative Variables in Econometrics. Cambridge University Press, Cambridge.

Marothia, D.K., 2001. Valuation of Day Use Recreation site: Application of Alternative Estimation Techniques. Indian journal of Agricultural Economics. University of Gulbarga. 56(3) 313-324.

Mbata, J., 2006. Estimating Household Willingness for Water Service in Rural Economy: the case of Kenya, Southern Botswana. Development of Southern Africa, 23 (1):29-43.

McCarthy, 2003. Demand for rainfall-index based insurance: A case study from Morocco International Food Policy Research Institute, U.S.A.

Mithcele, R.C. and T.R. Carson, 1989. Using survey to value public Goods: The contingent valuation method. Resources for the future, Washington, D.C.; The Johns HopkinsUniversity Press, Baltimore, U.S.A.

MoWR (Ministry of Water Resource of the Federal Democratic Republic of Ethiopia) 2007. Climate Change Adaptation Program of Action (NAPA) of Ethiopia. Addis Ababa, Ethiopia.

Patrick G. F., 1988. Mallee Wheat farmer's demand for crop and rainfall insurance, Australia Journal of Agricultural Economics, 32 (1): 37-49.

Paulos, A., 2002. Determinants for Farmers' willingness to participate in soil conservation practices in the highlands of Bale: The case of Dinsho Farming System Area. M.Sc. Thesis Presented to the School of Graduate Studies of Alemaya Universty.

Potential for scale and sustainability in weather index insurance for agricultural and rural livelihood. International Fund for Agriculture Development and World Food Program, Roma.

Rahman MA. 2013. Comparative Study on the Efficiency of Bangladeshi Conventional and Islamic Life Insurance Industry: A Non-Parametric Approach Asian Business Review, 3, 88-99.

Sakurai, T and T. Reardon., 1997. Potential demand for drought insurance in Burkinafaso and its determinants. American Journal of Agricultural Economics. 79 (4):1193-1207.

Sarris, A. 2002. The demand for commodity insurance by developing country agricultural producers: Theory and an application to cocoa in Ghana. Working Paper, DECRG and RDV. Washington, D.C.

Siegel, P.B. and J. Alwang., 1999. An asset based approach to social risk management: A conceptual approach, Social Protection Discussion Paper 9926, World Bank, Washington DC.

Skees, Jerry R. 2001, The Bad Harvest, Regulation, the CATO Review of Business and Government, 24: 16-21.

Stern, N.H., 2007. The economics of climate change: the. Cambridge University Press.

Storck, H., Bezabih Emana, Berhanu Adnew , Borowiecki, A.A and Shimelis w/ Hawariat, 1991. Farming systems and Farm Management Practices of Small-holders in the Hararghe Highlands. Farming System and Resource Economics in the Tropics.11: Wissenschafts Varlag Vauk Kiel KG, Germany

Thornton, P.K., P.G. Jones, T.M. Owiyo, R.L. Kruska, M. Herero, P. Kristijanson, A. Notenbaert, N. Bekele, 2006. Mapping Climate Vulnerablity and Poverty in Africa. Report to the Department for International Development, ILRI, Nairobi.

Ulrich Hess and Joanna Syroka, 2005. Weather based insurance in Southern Africa, Malawi. Agricultural and rural development discussion paper 13.

Vince E. Showers, and Joyce. Shotick, 1994. The effect of household characteristics on demand for insurance; a tobit analysis. The Journal of Risk and insurance, Vol 61, (3): 492-502.

Walker, T.S and James G.Ryan, 1990. Village and household economies in India's semi-arid tropics. Baltimore, Maryland, USA: The Johns Hopkins University Press.

World Bank, 2000. Mexico Rural Finance, Saving Mobilization Potential and Deposit Instruments in Marginal areas, Washington DC.

World Bank, 2005. Managing agricultural production risk innovation in developing countries. Report No. 32727-GLB. The International Bank for Reconstruction and Development. Washington , D.C.

World Bank, 2007. UN Department of Economic and social affairs division for sustainable development innovation briefs. Developing Index-based Insurance for Agriculture in Developing Countries, New York. 


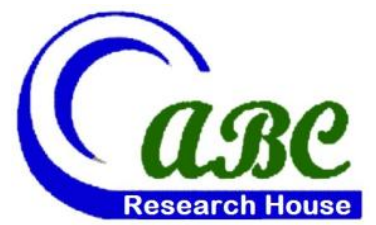

- Rd 4, Shyamoli, Dhaka-1207, Bangladesh

- Off Pantai Dalam, Kuala Lampur, Malaysia

- 3900 Woodhue Place, Alexandria, VA 22309, USA

www.abcreorg.weebly.com / www.abcjournals.net

Asian Business Consortium (ABC) is a multi-disciplinary research, training, publishing, digital library supporting and service house. Though founded in 2010 as the Business and Computing organization of Asia, it was reconstituted as the ABC in 2011. It has been working for creating and nurturing talents in USA, Malaysia and Bangladesh since its inception. As ABC is going global, it intends to open chapters in Australia, Germany, Japan, Pakistan, and other Asian countries in near future. The objectives of consortium are solely centered round the welfare and humane attitude of the founders who enthusiastically took up this noble cause and materialized it with a view to promote research and educational activities for the encouragement of scholars to develop their knowledge, to publish their analysis oriented scientific researches in international Journals, books, the task of organizing workshops, seminars, conferences, training, personality development programs and allied services.

In addition to research activities, ABC provides a good number of scholarships to the poor and meritorious students at various levels of education throughout the world. It plays an important role in the field of research by funding research projects and publishing the research papers. This consortium will unquestionably become the mouth-piece of the dark horses and unacknowledged scholar whose endowed and commendable contributions shall be provided an outlet keeping in mind the greater good of the larger society of the world.

$\mathrm{ABC}$ runs the following international referred journals for creating a platform to share the thoughts of professionals, scholars and academicians throughout the world.

\section{ABC Publications (ABC Journals)}

- Asian Accounting and Auditing Advancement (4A Journal)

- Asian Business Review (ABR)

- Asian Journal of Applied Sciences and Engineering (AJASE)

- Global Disclosure of Economics and Business (GDEB)

- $\quad$ ABC Journal of Advanced Research (ABC-JAR)

- International Journal of Reciprocal Symmetry and Theoretical Physics (IJRSTP)

- American Journal of Trade and Policy (AJTP)

- Asian Journal of Humanity, Art and Literature (AJHAL)

- Malaysian Journal of Medical and Biological Research (MJMBR)

- Asia Pacific Journal of Energy and Environment (APJEE)

- $\quad$ Engineering International (EI)

- $\quad$ ABC Research Alert (Online)

Each journal home page provides specific information for potential authors and subscribers. Open access policy, the quick review process, rich editorial boards and quality publications have already made $A B C$ Journals unique. ABC Journals are published under the direct supervisions of renowned academicians of the world.

Collaboration in Conference: $A B C$ considers high-quality conference papers for publication. Please contact us for detailed information.

Collaboration in Publishing: If you like to start writing a book, propose a new journal or advertise in $\mathrm{ABC}$ journals, please feel free to contact us. 